\title{
One country, many industries: Heterogeneity of Chinese OFDI motivations at meso level
}

\author{
Ping Lv ${ }^{\text {a, }}$, Louise Curran ${ }^{\mathrm{b}}$, Francesca Spigarelli ${ }^{\mathrm{c}}$, Elisa Barbieri ${ }^{\mathrm{d}}$ \\ ${ }^{a}$ University of Chinese Academy of Sciences, China \\ b TBS Business School, France, France \\ ${ }^{\mathrm{c}}$ University of Macerata, Italy \\ d $\mathrm{Ca}^{\prime}$ s;Foscari University of Venice, Italy
}

\section{A R T I C L E I N F O}

\section{Keywords:}

Industry-based view

Foreign direct investment

Investment motivations

China

Europe

\begin{abstract}
A B S T R A C T
Research on the stimulants for Chinese Foreign Direct Investment (FDI) is extensive. However most analysis incorporates theoretical models based on the Institution-Based View or, to a lesser extent, the Resource-Based View (RBV). These highlight the importance of the macro (country) and micro (firm) level, while largely ignoring the meso (industry) level. In addition, although investments are known to have several different motivations, stimulated by quite different factors, analysis tends to focus on aggregate FDI flows. We contribute to the literature by proposing an 'industry-based view' of FDI which takes account of heterogeneity across industries and FDI motivation. We apply this framework to Chinese OFDI in Europe, differentiating both in terms of investment motivations and sectoral characteristics at (meso) industry level and at (micro) firm level, in home and host countries. Using logistic and multinomial logistic models, our analysis confirms that different types of Chinese FDI (in terms of motivation) are stimulated by different industry-level characteristics in both home and host countries.
\end{abstract}

\section{Introduction}

In the early years of this century, Foreign Direct Investment (FDI) from China has rapidly become an important global phenomenon - the fourth most important source of FDI in 2019, after Japan, the US and the Netherlands (UNCTAD, 2020). Although there has been extensive work on FDI by Chinese (and other Emerging Market) firms (see work by Deng, 2013, Jormanainen \& Koveshnikov, 2012, Luo \& Zhang, 2016, Paul \& Benito, 2018), many unanswered questions remain. This paper seeks to shed light on underexplored aspects of the phenomenon, focusing on Chinese investment in Europe, where it has been widely spread across the economy. High-profile examples include Geely's acquisition of Volvo (cars) (Balcet, Wang, \& Richet, 2012), Zoomlion' s acquisition of Cifa (concrete machinery) (Spigarelli, Alon, \& Mucelli, 2015), and Kuka's acquisition by Midea (robotics) (Hooijmaaijers, 2019). In spite of the recent conclusion of the China-EU Comprehensive Agreement on Investment (CAI), such Chinese FDI has sometimes been controversial (EP., 2018; Nicolas, 2014). Some see the new EU FDI screening mechanism, which focuses on investments in certain critical industries like AI and energy, as particularly targeted towards Chinese companies (Duchatel, 2020). More detailed analysis can also help to inform the wider policy debate, by providing a better understanding of the different sectoral factors that impact on the motivations of Chinese

\footnotetext{
* Corresponding author.

E-mail addresses: lvping@ucas.ac.cn (P. Lv), 1.curran@tbs-education.fr (L. Curran), francesca.spigarelli@unimc.it (F. Spigarelli), elisa.barbieri@ unive.it (E. Barbieri).
} 
firms who invest in the EU.

The key novel aspects of our approach are, firstly, we highlight the important mitigating effect of FDI motivation. Although it is now many years since Dunning (1993) highlighted that a variety of motivations underlie FDI, analyses which differentiates between them is quite limited (Franco, Rentocchini, \& Vittucci Marzetti, 2010; He, Xie, \& Zhu, 2015; Makino, Lau, \& Yeh, 2002; Zhang \& Roelfsema, 2013). Most research on the determinants of FDI looks at aggregate figures. These include investments with quite different underlying motivations. The fact that results of such empirical research are sometimes conflictual may be due, in part, to a failure to fully account for this heterogeneity (Franco et al., 2010).

Secondly, we highlight the importance of sectoral differences to FDI motivation. As underlined by Jormanainen and Koveshnikov (2012), although analysis of the determinants of FDI is extensive, it has tended to focus on the macro and micro levels. There has been very little analysis of OFDI (either from China or elsewhere) at the meso level of industrial sectors. ${ }^{1}$ This is despite the fact that, building on the work of Porter (1990), it is widely accepted that the decision to invest is affected, not only by home (and host) institutions and firm-level resources, but also by the characteristics of the industry in which the firm is nested (e.g. Yang, Lim, Sakurai, \& Seo, 2009). Indeed, this was the basis for of the 'strategy tripod' s; approach to understanding FDI proposed by Peng, Wang, and Jiang (2008). Nevertheless, the industry-level factors which may impact on firms' s; FDI decisions have rarely been explored in depth.

The failure to consider industry differences in most work on FDI is problematic. Large sectoral variations could be expected in the importance of different factors of production, not least technology, while governments' s; industrial policies tend to focus on promoting certain 'strategic' industries (UNCTAD, $2018^{2}$ ). Indeed, the few studies that have analyzed FDI across industries have highlighted important differences, especially in relation to the impact of FDI on host countries (Bijsterbosch \& Kolasa, 2010; Fillat \& Woerz, 2011).

This paper seeks to contribute to these gaps in the literature by exploring FDI at the meso level, highlighting how the motivations behind Chinese OFDI are affected by the industrial context of the firm. Specifically, we address the interactions between industry-level characteristics in home and host countries and the motivations for FDI. For reasons of feasibility and data availability, the characteristics we explore are not exhaustive or, indeed, symmetrical across home and host countries. Our core objective is to draw attention to the pertinence of an industry-level approach to analyzing FDI motivation and lay the groundwork for future research exploring a wider range of industry characteristics and country dyads.

The paper is structured as follows. Firstly we will explore the key theoretical approaches to FDI, especially Chinese FDI and highlight the potential of better incorporating an 'industry-based' s; view in this context. We then summarize the key insights, as well as inconsistencies, which emerge from existing empirical analyses of aggregate FDI from China and into the EU. Drawing on work exploring FDI motivation and sectoral factors which may impact it, we propose a series of hypotheses on the interactions between FDI motivation and industrial characteristics. We present the data and methodology used to test these hypotheses and the results of our analysis. We conclude the paper by highlighting the key findings which emerge from this work, their policy implications and the further research avenues which they open, in addition to highlighting some research limitations.

\section{Theory and hypotheses development}

\subsection{Theoretical approaches to analyzing Chinese OFDI}

The literature on FDI is vast. In this paper we focus on the most pertinent studies which inform our understanding of Chinese OFDI. Although there is a burgeoning literature on the subject, many unanswered questions remain, especially the extent to which it can be explained by existing theories of FDI, or requires new theoretical (Knoerich, 2019) and/or empirical approaches (Ramamurti \& Hillemann, 2018).

In terms of the theoretical lenses through which Chinese OFDI has been analyzed, researchers have taken a variety of approaches. Some authors have argued that the widely accepted theories and models used to interpret firms' s; internationalization patterns fail to fully explain the Chinese case (Alon, Child, Li, \& McIntyre, 2011; Deng, 2012). Thus, China-specific (or more broadly Emerging-market MNE (EMNE)) theories have been developed and existing theories have been modified or adapted (Haasis \& Liefner, 2019). The best known of these novel theories are Mathews (2002) Linkage, Leverage, Learning (LLL) model and the 'Springboard Perspective' developed by Luo and Tung (2007). However, both pay relatively little attention to industry-level factors.

Several recent reviews of the literature on OFDI by Chinese and other EMNEs (which, in practice, overwhelmingly focuses on Chinese OFDI) provide a useful summary of the state of the art. These find that the resource-based view and the institution-based view are the literatures most commonly used to ground studies on Chinese OFDI (Deng, 2013; Paul \& Benito, 2018), although Luo and Zhang (2016) also note the use of Dunning' s OLI paradigm.

\footnotetext{
${ }^{1}$ Macro level studies have explored the impact of country factors, especially institutions (Guar, Kumar and Singh, 2014). Firm-level macro analyses have drawn on the Resource Based View (RBV) (Barney, 1991; Gaur et al., 2014; Trevino \& Grosse, 2002), as well as extensive work on the effect of firm heterogeneity on FDI (e.g. Greenaway \& Kneller, 2007; Rasciute et al., 2014). In the context of Chinese OFDI, several analyses adopt the Institution-Based View (Li, Xia, Shapiro, \& Lin, 2018; Peng et al., 2008; Xie \& Li, 2018) while others undertake more resource-based analyses (Cui, Jiang, \& Stening, 2011; Yan et al., 2018) and still another thread of research has begun to interrogate the interaction between firm heterogeneity in China and OFDI (Huang \& Zhang, 2017; Li, Liu, Yuan, \& Yu, 2017).

2 UNCTAD' s, 2018 World Investment Report focused on "Investments and new industrial policies". It found that since 2010 , over $80 \%$ of investment policy measures were directed at industry, with half of these considered to serve an industrial policy objective.
} 
Some scholars have sought to merge different theoretical approaches (i.e. resource-based, institution-based and industry-based views), most notably Peng et al. (2008) with their 'strategy tripod' s;. In the context of this paper, the most pertinent is the industry-based view, which highlights that '... differences in the level of internationalization stem from variations in the characteristics of industries.' (Wang, Hong, Kafouros, \& Boateng, 2012: 427). This view draws inspiration from the early work of Porter (1990), on the importance of varying competitive structures across industries to internationalization (Yang, Lim, et al., 2009), as well as analyses which have highlighted how internationalization intensities vary between companies from different sectoral contexts (Boter \& Holmquist, 1996; Curran \& Thorpe, 2013). The impacts of industry level factors on FDI may manifest themselves in both host and home countries, such that, as Cui and Jiang (2010) argue, specific industry contexts can act as both push and pull factors for FDI. Indeed, several studies have confirmed the importance of industry-level differences to Chinese OFDI activity (Cui \& Jiang, 2010; Gaur, Ma, \& Ding, 2018; Wang et al., 2012).

Many analyses concur that more multi-level analyses of Chinese (and EMNE) OFDI would enrich knowledge, although they disagree on which levels are most promising (Deng, 2013; Jormanainen \& Koveshnikov, 2012; Luo and Zhang, 2016; Paul \& Benito, 2018). Paul and Benito (2018) and Deng (2013) call for more micro-level studies, while Jormanainen and Koveshnikov (2012) highlight the need for more cross-industry analysis and Luo and Zhang (2016) the importance of analysis across different FDI motives. In this paper, we seek to respond to the latter two gaps in the literature by theorizing and analyzing how FDI motivations interact with a broad range of industry-level factors in both home and host countries. In so doing, we seek to contribute to a better understanding of the multi-level nature of FDI decision making.

\subsection{Determinants of Chinese OFDI}

Much of the work on Chinese OFDI has been conducted on aggregate flows at macro level, focusing on aspects like GDP, trade, growth and natural resources (Buckley et al., 2007; Kolstad \& Wiig, 2012). This early research paid little attention to the micro or meso levels. In response to critics (e.g. Morck, Yeung, \& Zhao, 2008), later studies started to integrate micro factors, sometimes also combined with meso-level sectoral indicators (Chen, Li, \& Yin, 2016; Gaur et al., 2018; Gaur, Kumar, \& Singh, 2014; Lu, Liu, \& Wang, 2011; Wang et al., 2012; Yang, Jiang, Kang, \& Ke, 2009). Key relevant findings from this literature include a link between FDI and firm level capabilities in R\&D and marketing (Chen et al., 2016; Gaur et al., 2014; Wang et al., 2012). Interactions between firm characteristics and their motivations for FDI have also been identified, in that R\&D capabilities encourage strategic asset seeking OFDI, while export experience and high levels of domestic competition encourage market seeking OFDI (Lu et al., 2011). However, others have found no difference in the determinants of FDI motivated by trade, compared to production (Wang et al., 2012).

Several of these studies explore industry-level factors, however they tend to be quite limited and focused on the home country. Characteristics which have been studied include the level of competition from domestic industry (Gaur et al., 2018; Lu et al., 2011; Wang et al., 2012; Yang, Jiang, et al., 2009 and Yang, Lim, et al., 2009) and from abroad (Gaur et al., 2018; Wang et al., 2012; Yang, Jiang, et al., 2009; Yang, Lim, et al., 2009); technology level or capital intensity of the industry (Chen et al., 2016; Lu et al., 2011; Wang et al., 2012); and lack of access to technology and human resources (Gaur et al., 2018). Most of these studies used data from before the global financial crisis, which had a major impact on Chinese FDI, including increasing flows into the EU (Nicolas, 2014). Our paper builds on this prior work, but includes a wider range of sectoral characteristics and FDI motivations, while leveraging very recent data.

In terms of existing studies of Inward FDI (IFDI) into Europe, most early studies focused on aggregate IFDI (Barrell \& Pain, 1999; Ford \& Strange, 1999). Only more recently has research begun to take a more disaggregated approach, with some limited work exploring the sectoral level. Rasciute and Pentecost (2010), underlined that sectoral factors have important mitigating effects on FDI in the EU. They conclude: '...country, industry and firm-level factors simultaneously determine the firm level investment location decision.' (2010: 39). In later work, Rasciute, Pentecost, and Ferret (2014) further explored these sectoral factors and found that the impacts of certain macro level factors like wage rates and unemployment levels differ across sectors.

\subsection{Motivations for Chinese OFDI}

Dunning (1993) defined four key motivations of FDI - market seeking, efficiency seeking, resource seeking and strategic-asset seeking. One would expect different factors to stimulate investment depending on its motivation, such that companies which are seeking new markets would be attracted by different host country attributes to those seeking more efficient production networks, or high-tech knowledge. However, as Franco et al. (2010) point out, much research on stimulating factors for FDI disregards this important framing factor. This may explain the sometimes-conflictual findings of different studies.

Franco et al. (2010) was a conceptual study. One of the few empirical analyses which differentiated between FDI motivations was by Makino et al. (2002). They focused on investment by Newly Industrialized Economies (NIE). Their analysis differentiated between asset-exploiting FDI (to exploit their existing assets) and asset-seeking FDI (to develop or acquire assets). Their results, that technologyand market- seeking motivations are more strongly associated with investment in developed countries while labor-seeking is more associated with that in developing countries were pertinent, if rather intuitive.

Prior analyses of Chinese OFDI which differentiates between investment motives is limited (Luo \& Zhang, 2016). Zhang and Roelfsema (2013) found that Chinese FDI in less advanced countries was mainly motivated by a desire to exploit regional markets and secure natural resources, whereas, in advanced economies, motivations were more related to exploiting network linkages and acquiring strategic resources. Lu et al. (2011) found that high levels of competition in a sector encourage market-seeking OFDI, while R\&D intensity encourages strategic asset seeking OFDI. Lv and Spigarelli (2015) found distinct differences in the destination of Chinese renewable energy OFDI in Europe, depending on its motivations. 
Thus, although much work on FDI analyses aggregate flows, prior research suggests that different types of OFDI are encouraged by different country and industry level characteristics. In this paper, we draw inspiration from this work, differentiating our analysis by investment motivation.

\subsection{Research hypothesis and theoretical framework on FDI motivation and industry specificity}

In this section, we develop a theoretical framework to link FDI motivations to the sectoral characteristics of different industries. Our objective is to provide a more disaggregated understanding of FDI by proposing a series of conceptual linkages between FDI motivations and industry characteristics in the home and host countries. The model and hypotheses are summarized in Fig. 1, which highlights the hypothesized interactions between FDI motivations and the different home and host country factors which we study.

The first characteristic we explore is the R\&D intensity of the industry. This has been shown to impact on OFDI activity at the firm level (Lu et al., 2011; Wang et al., 2012). Research on the impact of host country technological capacity on aggregate Chinese OFDI (He et al., 2015; Ramasamy, Yeung, \& Laforet, 2012) has failed to find a consistent relationship between the two. This may be related to the fact that, as outlined above, research-intensive companies are likely to engage in different types of OFDI, more focused on seeking strategic assets (Lu et al., 2011).

For research-intensive companies, a key strategic asset is knowledge, particularly that related to innovation. Indeed, as Shan and Song (1997) observed, multinational firms have long tended to internationalize R\&D, particularly in industries characterized by fast technological changes. This is coherent with the empirical evidence, which suggests that sectors with high R\&D intensity are more likely to seek strategic assets in developed countries like the EU (Knoerich \& Miedtank, 2018; Lu et al., 2011; Makino et al., 2002). We explore the impact of the R\&D intensity of the industry on FDI motivation through the following hypotheses:

Hypothesis 1a. Chinese R\&D oriented investments are more likely to be attracted to EU industries with higher R\&D intensity.

Hypothesis 1b. Firms operating in industries with higher R\&D intensity in China will be more likely to invest in R\&D activities in the EU.

In addition to technological capacity, several other industry characteristics may stimulate FDI with different motivations. In view of the availability of detailed and symmetrical data from China and EU states, the key characteristics which we integrate into our model are labor productivity, investment in production, importance to the local economy and growth rate. ${ }^{3}$ Although productivity has attracted a lot of study, it has almost entirely focused on the impacts of FDI on productivity (in the host and home countries) (e.g., Buckley et al., 2007; Gorodnichenko, Svejnar, \& Terrell, 2014; Knoerich, 2017). However, what interests us here is the inverse relationship - how industry level productivity in both host and home countries affects FDI and its motivation. This has been subject to limited study.

Early work by Cushman (1987) found that an increase in host country productivity attracted US FDI, while a rise in home productivity discourages it. Overall, he concludes '...growing non-US productivity appears to have been the most important of the various labor variables in determining direct investment flows over the period 1963-81.' (op.cit.: 183). In spite of this finding, subsequent research on the linkage has been limited and the results have been contradictory (Bellak, Leibrecht, \& Riedl, 2008; Ford \& Strange, 1999), while one Chinese study finds a bidirectional relationship, such that higher productivity was both a motivator and a result of IFDI (Zhang, 2002). We hypothesize that high host country productivity will attract manufacturing oriented FDI, as it can more effectively leverage this factor. Our hypothesis is the following:

Hypothesis 2a. Chinese manufacturing-oriented FDI is more likely to be attracted to EU industries with higher labor productivity.

In terms of the relationship between FDI and productivity in the home country, existing studies have tended to focus on how OFDI impacts on productivity, rather than the inverse. Overall, they find positive impacts (Huang \& Zhang, 2017; You \& Solomon, 2015), although the type of FDI and the nature of the industry may mitigate effects (Huang \& Zhang, 2017; You \& Solomon, 2015).

Several studies have explicitly explored whether there are variations in the relationship between OFDI and productivity in the home country depending on motivation, although they explore how different types of OFDI effect source country productivity, rather than the inverse (Huang \& Zhang, 2017; You \& Solomon, 2015). Of these, the most pertinent finding is that technology-seeking OFDI had a positive impact on productivity at home (Huang \& Zhang, 2017).

Thus, research indicates that strategic-asset seeking OFDI has positive impacts on productivity in the home economy or parent firm, while the source country and type of industry impact on such 'spillovers'. However, we have identified little substantial research exploring whether source country productivity impacts on either OFDI, or its motivation. One exception is the work of Herzer (2011) which highlights a bi-directional relationship between the two, such that: '...increased productivity is both a consequence and a cause of increased outward FDI.' (2011: 767).

In terms of the relationship between source country pre-entry productivity and FDI motivation, one recent analysis of Chinese firm level data found that more productive firms were more likely to engage in OFDI and this effect was stronger for investment aimed at

\footnotetext{
${ }^{3}$ Many characteristics could be used to define industry specificity, including availability of standards, technological change, competition intensity. Lu et al. (2011) use industry R\&D intensity and industry competition. Wang et al. (2012) use industry competition, inward FDI, and a dummy variable (high-tech). However, data availability is a key issue when choosing industry-level variables. This is the main reason for the limited variety of parameters used in the available literature, including this paper.
} 


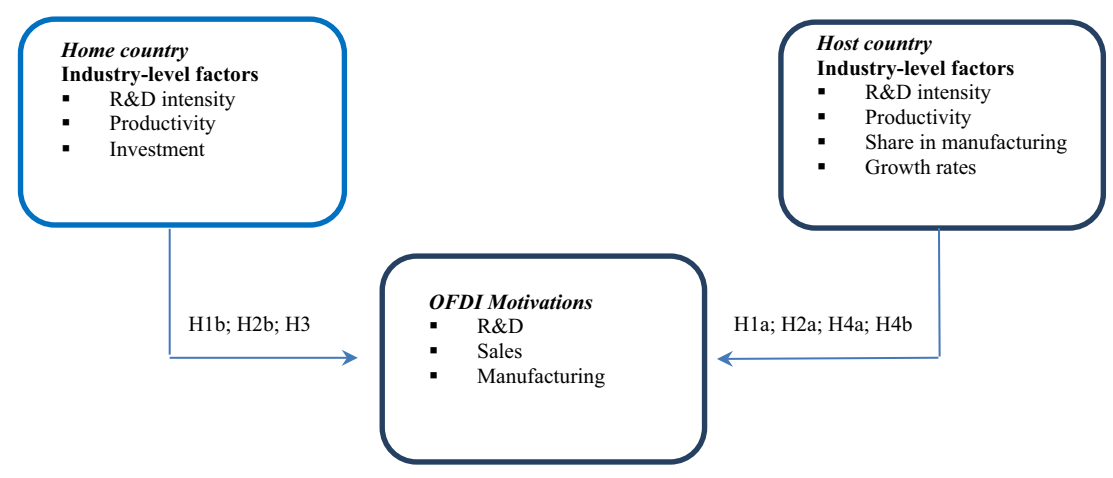

Fig. 1. Research framework and hypothesis.

local production and service trade (Yan, Zhang, Yanzhi, \& Jian, 2018). Others have emphasized that Chinese MNEs internationalize thanks to their knowledge/skills and technological capabilities (He, Khan, Lew, \& Fallon, 2019). Overall, more productive firms are likely to be characterized by high value-added production. Thus, we would expect such companies to invest in strategic asset seeking (knowledge and R\&D) and sales.

Hypothesis 2b. Firms operating in industries with higher labor productivity in China will be more likely to invest in R\&D and sales and service activities in the EU.

In terms of the relationships between home and host country investment and FDI, little prior research exists. Existing work tends to explore how IFDI effects host country investment, specifically, whether it crowds-out domestic private investment (Kamaly, 2014; Rath \& Bal, 2014). A rare study on the effects of OFDI on investment in the source country, which also accounted for different FDI motivations, is Hejazi and Pauly's (2003) study in Canada. They found that OFDI to the UK and US (which were assumed to be motivated by market seeking, or production sharing), had positive impacts on Gross Fixed Capital Formation (GFCF), while that to other destinations (which were assumed to be efficiency seeking) had negative impacts.

We have not identified any studies which explore the relationship between pre-entry investment levels in the source country and OFDI, although high levels of domestic investment could be expected to impact on both the decision and the motivation of the investment. One possibility, highlighted by Leonidou, Katsikeas, Palihawadana, and Spyropoulou (2007), is that high levels of domestic investment encourage firms to seek new markets, in order to exploit economies of scale. Thus, high investment levels in the source country could be expected to be associated with both sales and manufacturing-oriented OFDI.

Hypothesis 3. Firms operating in industries with higher investment in production in China will be more likely to invest in sales and service or manufacturing activities in the EU.

Finally, with respect to the industry-level competitiveness of the host country, the importance of an industry to the economy and its growth rate may also impact on investment motivation. Industries which are important to the local economy are likely to have strategic assets of interest to less mature 'infant' industries, such as those in China (Ramamurti \& Hillemann, 2018). Thus, we expect such firms to be attracted less by the market and more by host industry accumulated knowledge. Accordingly, we propose that firms investing in important local industries are more motivated by technology or manufacturing know-how in the EU host country, than sales and service.

Hypothesis 4a. Chinese R\&D or manufacturing-oriented FDI is more likely to be attracted to EU industries representing a higher share of total manufacturing.

On the other hand, an industry with a higher growth rate, indicates growing levels of accumulated knowledge and technology, but high uncertainty (Luo \& Tan, 1997). In line with hypothesis 1, this may encourage Chinese firms to invest in manufacturing or R\&D activities, rather than sales and service.

Hypothesis 4b. Chinese R\&D or manufacturing-oriented FDI is more likely to be attracted to EU industries with higher growth rates.

\section{Methodology}

\subsection{Research context}

We test our theoretical framework by exploring Chinese investment into the EU. The region has been a particularly important destination for Chinese OFDI in recent years, both for traditional 'market-seeking' Chinese investment and that focused on technology and production (Huang \& Zhang, 2017; Knoerich \& Miedtank, 2018). The heterogeneity of the EU means that patterns of FDI differ across countries (Baker \& McKenzie, 2015). Europe thus provides a varied context in which to analyze the relationship between the motives of Chinese OFDI and industry level factors. 


\subsection{Data and samples}

We test our hypotheses using data on all Chinese manufacturing firms with foreign subsidiaries in an EU country. ${ }^{4}$ In line with previous research (Lu et al., 2011), we focus on manufacturing firms, to control for the fundamental differences that could be expected between the stimulating factors and motivations of such firms and others, like those engaged in services. The analysis is based on industry-level data from the National Bureau of Statistics of China (NBSC) and Statistical Office of the European Communities (Eurostat). Our firm-level data comes from Ministry of Commerce of China (MofCom) and covers both greenfield and non-greenfield (e. g., M\&A, joint venture) investments.

The starting sample included 1199 investments by Chinese manufacturing firms in the EU from 2002 to 2015 . However, as industry-level data for some host countries was missing, ${ }^{5}$ the final sample includes 794 investments from 2006 to 2015 . Our analysis focuses on manufacturing, sub-divided into 18 NACE sectors. As our dataset predates the exit of the UK from the EU, we include it in the analysis.

As shown in Fig. 2 Chinese OFDI has not been spread homogeneously across the EU. Germany has been the most popular destination, followed by the UK, the Netherlands and Italy. In most cases, although the main motivation for investment was sales and service, followed by manufacturing and R\&D (see Section 3.2 for details), motivations differed markedly by industrial sector.

Table A in the Appendix provides details of the sectoral structure of our sample. The sectors where Chinese OFDI was most prevalent $(43.8 \%$ of the total) were electrical machinery and machinery and equipment.

Although the database is longitudinal, covering investment over a ten-year period, our analysis is cross-sectional, rather than panel. This is because more than $90 \%$ of the sample firms undertook a single investment over the period. Fixed-effects models explore the determinants of within-observations variability. They are inappropriate in the absence of such variability (Allison, 2009). Prior analyses of FDI in Europe have applied similar discrete choice models (Disdier \& Mayer, 2004; Rasciute \& Pentecost, 2010).

\subsection{Measures}

All Chinese firms investing abroad must apply for a permit from MofCom. Our database is based on data collected from these firmlevel applications, which provide the year of investment, destination country and detailed description of overseas activities. ${ }^{6}$

In line with the objectives of this study, our dependent variable is a firm' s motivation for OFDI. We identified these motivations from the detailed descriptions of firms' $s$; overseas activities provided. Activities were hand-coded into three categories: manufacturing, sales and service and R\&D. 'Manufacturing' refers to investment related to production and assembling. 'Sales and service', to investment related to export, distribution and after-sale service, while 'R\&D' s; refers to investments in research and development, or the acquisition of know-how. These motivations are not exclusive. A company can declare more than one category (for example, R\&D and manufacturing).

In our empirical analysis, the three motivations are represented with three dummy variables labeled as 1 when the OFDI is classified as having that motivation, and 0 otherwise. The data on each motivation is shown in Table 1 . The number of observations of firms without sales and service motivation is quite low and thus this category is, to some extent, underrepresented. This could undermine the significance of relevant empirical results. As explained below, we undertake some further adjustment to address this issue.

Our data indicates that the motivations for Chinese OFDI in EU manufacturing sectors have evolved over time (see Fig. 3). The share of firms motivated by sales and service motivation declined from nearly $70 \%$ in 2006 to less than $50 \%$ in 2015 . At the same time, the other two motivations increased, especially R\&D, where the share rose from $9 \%$ to $21 \%$.

In line with our hypotheses and theoretical framework, the independent variables for this study measure key industry-level factors in the home (China) and host (EU) countries. In terms of host country factors, industry-level R\&D intensity is measured by business enterprise R\&D expenditure (BERD) of the sector divided by its' s; value added (VA) - (EU industry R\&D intensity). ${ }^{7}$ Industry level labor productivity is operationalized as VA divided by employment in the specific industry sector (EU industry productivity). The importance to the host economy is represented by the ratio of VA of the sector to total manufacturing (EU relevance of the sector). Sectoral growth is represented by the growth rate of sectoral VA (EU sectoral growth).

Regarding home country factors, we capture R\&D intensity using the sectoral expenditure on R\&D divided by the revenue from core business (Chinese industry R\&D intensity). In terms of labor productivity, this is usually represented by value added (VA) divided by total employment in the specific industry sector. However, VA data is poor in China. We therefore chose to use revenue from core business, divided by total employment, as a proxy for sector level labor productivity (Chinese industry labor productivity). Comparing this data with the limited figures available on VA, we find the two to be very similar. Sectoral productivity performance is similarly measured by the growth rate of revenue from core business divided by sectoral employment (Chinese industry productivity growth).

\footnotetext{
${ }^{4}$ Although some scholars argue that the importance of country level factors in attracting FDI to EU countries has been reduced by the high level of EU integration (Buckley, Clegg, Forsans, \& Reilly, 2001), prior analyses confirm that the country level remains important to investors in the EU (Basile, Castellani, \& Zanfei, 2009; Crescenzi et al., 2016).

${ }^{5}$ Greece, Latvia, Malta and Slovenia are excluded from the analysis.

${ }^{6}$ Commitments/announced investment and reinvestment are not included in our database

7 The definition of EU industry R\&D intensity is different in that the indicator VA is applied here rather than the revenue from core business due to the limitation of data availability in the home country side. In Eurostat, VA is the gross income from operating activities after adjusting for operating subsidies and indirect taxes.
} 


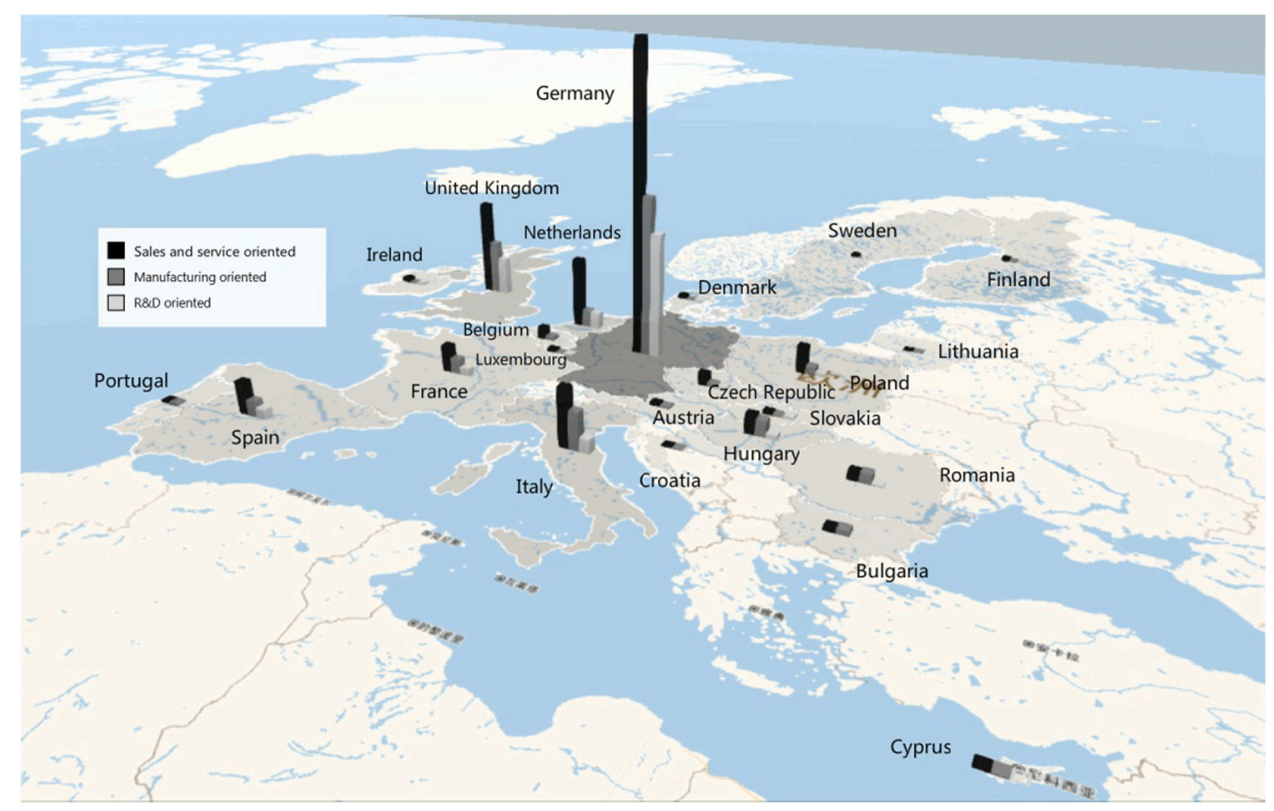

Fig. 2. Map of Chinese OFDI in EU countries (cumulative number, 2006-2015).

Table 1

The three dependent variables.

\begin{tabular}{lll}
\hline Dependent variables & Dummy & Number \\
\hline Manufacturing & 0 & 409 \\
& 1 & 385 \\
Sales and service & 0 & 52 \\
& 1 & 742 \\
R\&D & 0 & 538 \\
& 1 & 256 \\
Total & & 794 \\
\hline
\end{tabular}

Source: authors' s; elaborations on MofCom data.

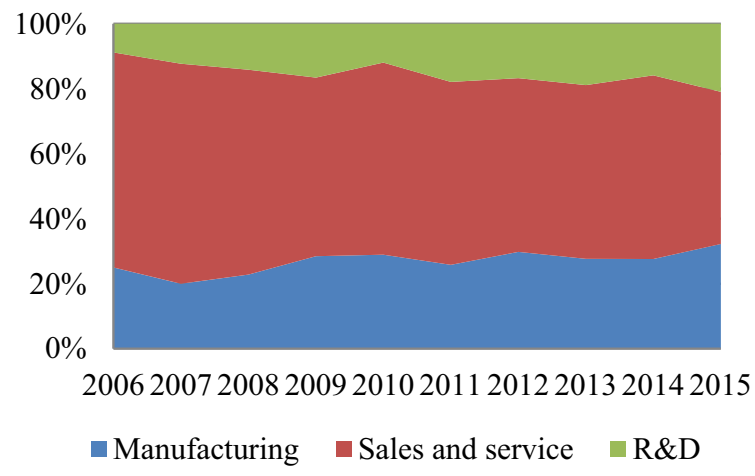

Fig. 3. Evolution of Motivations for Chinese OFDI in EU manufacturing sectors.

Finally, to capture home country sectoral investment levels, we use investment in fixed assets divided by employment (Chinese industry investment propensity).

We also incorporated several control variables. The importance of the technological level of the host economy to Chinese OFDI has 
been shown to vary by type of country (with it being important in developed countries) and over time (it has been more important in more recent years) (Zhang \& Roelfsema, 2013). In order to assess the impact of different sectoral technological intensities, we group manufacturing industries into four categories based on the OECD' s (2013) classification i.e. high-technology, medium-high-technology, medium-low-technology and low-technology, shown in Table A. ${ }^{8}$ On this basis, we created four dummy variables equal to 1 if the OFDI is in that category and 0 otherwise.

Size of the market and its growth rate have consistently been found to be important motivators for FDI (Buckley et al., 2007; Kolstad \& Wiig, 2012). We control for market size by including EU host country GDP and use GDP per capita as a measure of market affluence. Furthermore, previous studies have found that FDI is attracted to areas where other firms are already clustered, because of knowledge spillovers, although investors may also avoid these areas because of increased competitive pressure (Crescenzi, Pietrobelli, \& Rabellotti, 2016; Disdier \& Mayer, 2004). Consistent with Disdier \& Mayer, 2004, we control for such agglomeration effects by measuring the cumulated number of Chinese investments in all manufacturing located in the same host country in the year prior to the OFDI.

In terms of other controls, industry specificity is important in China, where the Government has identified certain key industries as strategic (Barbieri et al., 2019) and restricted OFDI in others (Knoerich \& Miedtank, 2018). We account for sectoral variation in political support within China through several variables. In line with Wang et al. (2012), we include a dummy variable on 'encouraged industries' for sectors which were 'encouraged' s; to undertake OFDI by the Chinese government. ${ }^{9}$ The dummy variable equals 1 if the industry was encouraged after 2008 and 0 otherwise.

In line with Chen, Jiang, \& Weng (2020), we also include a control dummy for 'prioritized industries', identified within the Eleventh (2006-2010) and Twelfth (2011-2015) Five-Year Plans (see Table A in the Appendix). The variable equals 1 if the sector was prioritized and 0 otherwise.

State ownership in an industry is often regarded as institution-related capital (Lu \& Yao, 2006), while firms in industries with higher state ownership benefit from various preferential policies and government support for OFDI (Luo, Xue, \& Han, 2010). We therefore include government participation, measured by the percentage of state-owned assets in each industry.

Finally, the intensity of competition in a sector may be positively related with the levels of OFDI (Yang, Jiang, et al., 2009; Yang, Lim, et al., 2009), as competitive pressures may encourage international expansion. In line with Wang et al. (2012), we use data from the National Bureau of Statistics of China on growth in the number of firms with annual revenue from the sector of at least 20 million RMB. Details of all variables and data sources are provided in Table B in the Annex. Table 2 shows the correlations of the variables used in our analysis. Their variance inflation factors were found to be below 10, indicating that our data does not show serious multicollinearity.

\subsection{Analytical approach}

We firstly perform an econometric analysis through three distinct logistic regression models related to the three types of investment motivations. The three models have the same independent variables, but different dependent variables, related to OFDI motivations. Our choice of technique is based on the dichotomous attributes of the dependent variables. Model 1 only includes the control variables related to industry classification and country-level characteristics. Model 2 also incorporates industry-level variables for EU host countries, while model 3 includes those of China (home country). Model 4 presents the full model with all variables. The home and host country control variables are lagged one year on the investment. The regression models are:

$$
\begin{aligned}
& \text { Manufacturing }_{i, t}=\beta_{0}+\beta_{1} Z_{i . t-1}+\varepsilon_{i . t} \\
& \text { Manufacturing }_{i, t}=\beta_{0}+\beta_{1} \text { Host }_{i . t-1}+\beta_{2} Z_{i . t-1}+\varepsilon_{i . t} \\
& \text { Manufacturing }_{i, t}=\beta_{0}+\beta_{1} \text { Home }_{i . t-1}+\beta_{2} Z_{i . t-1}+\varepsilon_{i . t} \\
& \text { Manufacturing }_{i, t}=\beta_{0}+\beta_{1} \text { Host }_{i . t-1}+\beta_{2} \text { Home }_{i . t-1}+\beta_{3} Z_{i . t-1}+\varepsilon_{i . t} \\
& \text { Sales and service } e_{i, t}=\beta_{0}+\beta_{1} Z_{i . t-1}+\varepsilon_{i . t} \\
& \text { Sales and service } i, t=\beta_{0}+\beta_{1} \text { Host }_{i . t-1}+\beta_{2} Z_{i . t-1}+\varepsilon_{i . t} \\
& \text { Sales and service } \\
& \text { Salt }=\beta_{0}+\beta_{1} \text { Home }_{i . t-1}+\beta_{2} Z_{i . t-1}+\varepsilon_{i . t} \\
& \text { Service }_{i, t}=\beta_{0}+\beta_{1} \text { Host }_{i . t-1}+\beta_{2} \text { Home }_{i . t-1}+\beta_{3} Z_{i . t-1}+\varepsilon_{i . t}
\end{aligned}
$$

\footnotetext{
${ }^{8}$ Based on our data in Table 1, Chinese investments in high-technology, medium-high-technology, medium-low-technology and low-technology account for $13.0 \%, 58.9 \%, 10.7 \%$ and $17.4 \%$ respectively of Chinese investment in EU in manufacturing.

${ }^{9}$ According to the Guiding Directories of Target Nations and Industries for OFDI, issued by the State Council of China (2008), OFDI in the following nineteen sectors is encouraged: textiles; clothing; fiber; wood products; paper and pulp; agricultural machinery; polyethylene; fertilizer; medicine; sinter pellet and ferrochrome production; non-ferrous metal smelting; civil satellite communications; digital machine tool; new building materials; measuring tool; bearing and instruments; automotive; household electronics; electronics and information related products.
} 
Table 2

Correlation matrix.

\begin{tabular}{|c|c|c|c|c|c|c|c|c|c|c|c|c|c|c|c|c|}
\hline Variables & VIF & (1) & (2) & (3) & (4) & (5) & (6) & (7) & (8) & (9) & (10) & (11) & (12) & (13) & (14) & (15) \\
\hline (1) EU industry R\&D intensity & 1.81 & 1 & & & & & & & & & & & & & & \\
\hline (2) EU industry productivity & 2.61 & $0.30^{*}$ & 1 & & & & & & & & & & & & & \\
\hline (3) EU relevance of the sector & 1.4 & -0.04 & 0.17 * & 1 & & & & & & & & & & & & \\
\hline (4) EU sectoral growth & 1.14 & $0.21 *$ & $0.17 *$ & 0.05 & 1 & & & & & & & & & & & \\
\hline (5) Chinese industry R\&D intensity & 2.67 & $0.51 *$ & $0.41^{*}$ & 0.05 & $0.11 *$ & 1 & & & & & & & & & & \\
\hline (6) Chinese industry labor productivity & 2.88 & $0.10^{*}$ & $0.44 *$ & 0.28 * & $0.11 *$ & $0.36^{*}$ & 1 & & & & & & & & & \\
\hline (7) Chinese industry productivity growth & 1.39 & 0.01 & $0.14 *$ & -0.14 * & $0.12^{*}$ & $-0.16^{*}$ & $-0.23^{*}$ & 1 & & & & & & & & \\
\hline (8) Chinese industry investment propensity & 3.17 & -0.03 & $0.36^{*}$ & $0.41^{*}$ & 0.06 & $0.40^{*}$ & $0.72^{*}$ & $-0.26^{*}$ & 1 & & & & & & & \\
\hline (9) Host GDP & 1.84 & $0.08^{*}$ & $0.30^{*}$ & $0.19^{*}$ & $-0.07^{*}$ & $0.26^{*}$ & 0.17 * & -0.05 & 0.17 * & 1 & & & & & & \\
\hline (10) Host GDP per capita & 2.71 & $0.29 *$ & $0.60^{*}$ & $0.12^{*}$ & -0.02 & $0.33^{*}$ & $0.24 *$ & -0.04 & $0.22 *$ & $0.63^{*}$ & 1 & & & & & \\
\hline (11) Agglomeration & 1.17 & $-0.11^{*}$ & -0.06 & $-0.08^{*}$ & -0.03 & $-0.11^{*}$ & -0.14 * & $-0.12^{*}$ & -0.06 & -0.03 & -0.01 & 1 & & & & \\
\hline (12) Encouraged industries & 2.93 & $0.15^{*}$ & $0.16^{*}$ & $0.12^{*}$ & $0.08^{*}$ & $0.43^{*}$ & $0.28^{*}$ & $-0.30^{*}$ & 0.21 * & $0.16^{*}$ & $0.19^{*}$ & $0.10^{*}$ & 1 & & & \\
\hline (13) Prioritized industries & 1.54 & $0.16^{*}$ & $0.24 *$ & $0.12^{*}$ & $0.07 *$ & $0.55^{*}$ & 0.61 * & $-0.35^{*}$ & $0.62^{*}$ & $0.14 *$ & $0.18^{*}$ & $0.09^{*}$ & $0.37 *$ & 1 & & \\
\hline (14) Government participation & 2.06 & $0.32 *$ & $0.53^{*}$ & $0.23^{*}$ & $0.14 *$ & $0.34 *$ & $0.52 *$ & -0.04 & $0.43^{*}$ & $0.14 *$ & $0.23^{*}$ & $-0.17^{*}$ & 0.02 & $0.17^{*}$ & 1 & \\
\hline (15) Industry competition intensity & 1.34 & -0.03 & $-0.10^{*}$ & -0.01 & $-0.09^{*}$ & $-0.27^{*}$ & $-0.25^{*}$ & $0.18^{*}$ & $-0.32^{*}$ & -0.06 & $-0.08^{*}$ & $-0.08^{*}$ & $-0.17^{*}$ & $-0.46^{*}$ & 0.03 & 1 \\
\hline
\end{tabular}

Note: * shows significance at the 0.05 level. 
Table 3

Logistic regressions.

\begin{tabular}{|c|c|c|c|c|c|c|c|c|c|c|c|c|}
\hline & \multicolumn{4}{|c|}{ Manufacturing } & \multicolumn{4}{|c|}{ Sales and service } & \multicolumn{4}{|l|}{$\underline{R} \& \mathrm{D}$} \\
\hline & ModelA1 & ModelA2 & ModelA3 & ModelA4 & ModelB1 & ModelB2 & ModelB3 & ModelB4 & ModelC1 & ModelC2 & ModelC3 & ModelC4 \\
\hline EU industry R\&D intensity & & $\begin{array}{l}-0.030 * \\
(0.02)\end{array}$ & & $\begin{array}{l}-0.018 \\
(0.02)\end{array}$ & & $\begin{array}{l}0.013 \\
(0.04)\end{array}$ & & $\begin{array}{l}-0.013 \\
(0.05)\end{array}$ & & $\begin{array}{l}0.034^{*} \\
(0.02)\end{array}$ & & $\begin{array}{l}0.026 \\
(0.02)\end{array}$ \\
\hline EU industry productivity & & $\begin{array}{l}-0.166^{* * * *} \\
(0.05)\end{array}$ & & $\begin{array}{l}-0.217^{* * *} \\
(0.06)\end{array}$ & & $\begin{array}{l}0.062 \\
(0.13)\end{array}$ & & $\begin{array}{l}0.042 \\
(0.17)\end{array}$ & & $\begin{array}{l}-0.016 \\
(0.05)\end{array}$ & & $\begin{array}{l}-0.052 \\
(0.05)\end{array}$ \\
\hline EU relevance of the sector & & $\begin{array}{l}0.090^{* * * *} \\
(0.02)\end{array}$ & & $\begin{array}{l}0.065^{* * * *} \\
(0.02)\end{array}$ & & $\begin{array}{l}-0.023 \\
(0.04)\end{array}$ & & $\begin{array}{l}0.026 \\
(0.05)\end{array}$ & & $\begin{array}{l}0.012 \\
(0.02)\end{array}$ & & $\begin{array}{l}0.034 \\
(0.03)\end{array}$ \\
\hline EU sectoral growth & & $\begin{array}{l}0.004 \\
(0.01)\end{array}$ & & $\begin{array}{l}0.005 \\
(0.01)\end{array}$ & & $\begin{array}{l}-0.043^{* * *} \\
(0.02)\end{array}$ & & $\begin{array}{l}-0.047^{* * *} \\
(0.02)\end{array}$ & & $\begin{array}{l}-0.014 \text { * } \\
(0.01)\end{array}$ & & $\begin{array}{l}-0.014^{*} \\
(0.01)\end{array}$ \\
\hline Chinese industry R\&D intensity & & & $\begin{array}{l}0.377 \\
(0.56)\end{array}$ & $\begin{array}{l}-0.298 \\
(0.61)\end{array}$ & & & $\begin{array}{l}-0.178 \\
(1.22)\end{array}$ & $\begin{array}{l}-0.262 \\
(1.46)\end{array}$ & & & $\begin{array}{l}1.296^{* * *} \\
(0.62)\end{array}$ & $\begin{array}{l}0.816 \\
(0.66)\end{array}$ \\
\hline Chinese industry labor productivity & & & $\begin{array}{l}0.034 \\
(0.05)\end{array}$ & $\begin{array}{l}0.079 \\
(0.05)\end{array}$ & & & $\begin{array}{l}-0.037 \\
(0.10)\end{array}$ & $\begin{array}{l}-0.034 \\
(0.10)\end{array}$ & & & $\begin{array}{l}0.099^{*} \\
(0.06)\end{array}$ & $\begin{array}{l}0.117^{*} \\
(0.06)\end{array}$ \\
\hline Chinese industry productivity growth & & & $\begin{array}{l}-0.033 \\
(0.03)\end{array}$ & $\begin{array}{l}-0.002 \\
(0.03)\end{array}$ & & & $\begin{array}{l}0.182^{*} \\
(0.10)\end{array}$ & $\begin{array}{l}0.210^{* * *} \\
(0.10)\end{array}$ & & & $\begin{array}{l}0.066^{* *} \\
(0.03)\end{array}$ & $\begin{array}{l}0.078^{* * *} \\
(0.03)\end{array}$ \\
\hline Chinese industry invest propensity & & & $\begin{array}{l}0.099 * * * \\
(0.02)\end{array}$ & $\begin{array}{l}0.074^{* * *} \\
(0.03)\end{array}$ & & & $\begin{array}{l}-0.062 \\
(0.04)\end{array}$ & $\begin{array}{l}-0.078 \\
(0.05)\end{array}$ & & & $\begin{array}{l}-0.033 \\
(0.02)\end{array}$ & $\begin{array}{l}-0.042 \\
(0.03)\end{array}$ \\
\hline Host GDP & $\begin{array}{l}33.906^{* *} \\
(16.70)\end{array}$ & $\begin{array}{l}36.447 * * \\
(17.10)\end{array}$ & $\begin{array}{l}32.282^{*} \\
(16.91)\end{array}$ & $\begin{array}{l}33.967^{* *} \\
(17.25)\end{array}$ & $\begin{array}{l}-14.619 \\
(28.06)\end{array}$ & $\begin{array}{l}-9.369 \\
(30.13)\end{array}$ & $\begin{array}{l}-19.956 \\
(28.65)\end{array}$ & $\begin{array}{l}-17.533 \\
(30.15)\end{array}$ & $\begin{array}{l}18.421 \\
(16.07)\end{array}$ & $\begin{array}{l}19.095 \\
(16.26)\end{array}$ & $\begin{array}{l}19.116 \\
(16.04)\end{array}$ & $\begin{array}{l}19.739 \\
(16.40)\end{array}$ \\
\hline Host GDP per capita & $\begin{array}{l}-45.48^{* * *} \\
(17.48)\end{array}$ & $\begin{array}{l}-47.830 * * * \\
(17.90)\end{array}$ & $\begin{array}{l}-43.470 * * \\
(17.71)\end{array}$ & $\begin{array}{l}-44.853^{* *} \\
(18.05)\end{array}$ & $\begin{array}{l}24.556 \\
(29.51)\end{array}$ & $\begin{array}{l}19.085 \\
(31.61)\end{array}$ & $\begin{array}{l}30.761 \\
(30.10)\end{array}$ & $\begin{array}{l}28.013 \\
(31.70)\end{array}$ & $\begin{array}{l}-19.377 \\
(16.83)\end{array}$ & $\begin{array}{l}-19.359 \\
(17.04)\end{array}$ & $\begin{array}{l}-20.537 \\
(16.80)\end{array}$ & $\begin{array}{l}-20.443 \\
(17.18)\end{array}$ \\
\hline Agglomeration & $\begin{array}{l}0.050^{* * *} \\
(0.02)\end{array}$ & $\begin{array}{l}0.063^{* * *} \\
(0.02)\end{array}$ & $\begin{array}{l}0.058^{* * *} \\
(0.02)\end{array}$ & $\begin{array}{l}0.073^{* * *} \\
(0.03)\end{array}$ & $\begin{array}{l}-0.063 \\
(0.04)\end{array}$ & $\begin{array}{l}-0.060 \\
(0.04)\end{array}$ & $\begin{array}{l}-0.076^{*} \\
(0.04)\end{array}$ & $\begin{array}{l}-0.074 \text { * } \\
(0.05)\end{array}$ & $\begin{array}{l}-0.017 \\
(0.03)\end{array}$ & $\begin{array}{l}-0.027 \\
(0.03)\end{array}$ & $\begin{array}{l}-0.021 \\
(0.03)\end{array}$ & $\begin{array}{l}-0.022 \\
(0.03)\end{array}$ \\
\hline Encouraged industries & $\begin{array}{l}-0.559^{*} \\
(0.33)\end{array}$ & $\begin{array}{l}-0.869^{* *} \\
(0.34)\end{array}$ & $\begin{array}{l}-0.184 \\
(0.37)\end{array}$ & $\begin{array}{l}-0.621 \\
(0.39)\end{array}$ & $\begin{array}{l}-0.302 \\
(0.69)\end{array}$ & $\begin{array}{l}0.027 \\
(0.74)\end{array}$ & $\begin{array}{l}-0.314 \\
(0.77)\end{array}$ & $\begin{array}{l}-0.064 \\
(0.81)\end{array}$ & $\begin{array}{l}0.134 \\
(0.35)\end{array}$ & $\begin{array}{l}0.130 \\
(0.37)\end{array}$ & $\begin{array}{l}0.120 \\
(0.40)\end{array}$ & $\begin{array}{l}-0.047 \\
(0.43)\end{array}$ \\
\hline Prioritized industries & $\begin{array}{l}-0.338 \\
(0.53)\end{array}$ & $\begin{array}{l}-0.192 \\
(0.54)\end{array}$ & $\begin{array}{l}-0.266 \\
(0.55)\end{array}$ & $\begin{array}{l}-0.092 \\
(0.56)\end{array}$ & $\begin{array}{l}-1.157 \\
(1.21)\end{array}$ & $\begin{array}{l}-1.387 \\
(1.22)\end{array}$ & $\begin{array}{l}-0.865 \\
(1.26)\end{array}$ & $\begin{array}{l}-0.999 \\
(1.26)\end{array}$ & $\begin{array}{l}-0.814 \\
(0.72)\end{array}$ & $\begin{array}{l}-0.898 \\
(0.73)\end{array}$ & $\begin{array}{l}-0.947 \\
(0.74)\end{array}$ & $\begin{array}{l}-1.009 \\
(0.75)\end{array}$ \\
\hline Government participation & $\begin{array}{l}3.521^{*} \\
(2.12)\end{array}$ & $\begin{array}{l}6.391 \text { ** } \\
(2.78)\end{array}$ & $\begin{array}{l}-0.291 \\
(2.53)\end{array}$ & $\begin{array}{l}3.023 \\
(3.06)\end{array}$ & $\begin{array}{l}-1.144 \\
(3.72)\end{array}$ & $\begin{array}{l}0.044 \\
(6.64)\end{array}$ & $\begin{array}{l}1.371 \\
(4.98)\end{array}$ & $\begin{array}{l}4.303 \\
(7.48)\end{array}$ & $\begin{array}{l}4.680^{* *} \\
(2.15)\end{array}$ & $\begin{array}{l}3.094 \\
(2.89)\end{array}$ & $\begin{array}{l}3.847 \\
(2.66)\end{array}$ & $\begin{array}{l}2.728 \\
(3.24)\end{array}$ \\
\hline Industry competition intensity & $\begin{array}{l}-0.646 \\
(1.57)\end{array}$ & $\begin{array}{l}0.021 \\
(1.60)\end{array}$ & $\begin{array}{l}2.236 \\
(1.74)\end{array}$ & $\begin{array}{l}1.532 \\
(1.77)\end{array}$ & $\begin{array}{l}-4.997 \\
(3.39)\end{array}$ & $\begin{array}{l}-4.038 \\
(3.32)\end{array}$ & $\begin{array}{l}-7.267^{* *} \\
(3.64)\end{array}$ & $\begin{array}{l}-6.577^{*} \\
(3.70)\end{array}$ & $\begin{array}{l}-0.479 \\
(1.71)\end{array}$ & $\begin{array}{l}-0.366 \\
(1.76)\end{array}$ & $\begin{array}{l}-1.840 \\
(1.92)\end{array}$ & $\begin{array}{l}-2.050 \\
(1.96)\end{array}$ \\
\hline High-tech industry & $\begin{array}{l}0.962^{* *} \\
(0.39)\end{array}$ & $\begin{array}{l}2.474^{* * * *} \\
(0.55)\end{array}$ & $\begin{array}{l}0.760 \\
(0.78)\end{array}$ & $\begin{array}{l}2.791^{* * *} \\
(0.94)\end{array}$ & $\begin{array}{l}1.560 \\
(0.96)\end{array}$ & $\begin{array}{l}1.306 \\
(1.34)\end{array}$ & $\begin{array}{l}1.647 \\
(1.84)\end{array}$ & $\begin{array}{l}2.183 \\
(2.34)\end{array}$ & $\begin{array}{l}2.208^{* * *} \\
(0.52)\end{array}$ & $\begin{array}{l}1.803^{* * * *} \\
(0.65)\end{array}$ & $\begin{array}{l}0.440 \\
(0.91)\end{array}$ & $\begin{array}{l}0.977 \\
(1.05)\end{array}$ \\
\hline Medium-high tech industry & $\begin{array}{l}0.433 \\
(0.33)\end{array}$ & $\begin{array}{l}0.942^{* * *} \\
(0.37)\end{array}$ & $\begin{array}{l}-0.519 \\
(0.64)\end{array}$ & $\begin{array}{l}0.669 \\
(0.72)\end{array}$ & $\begin{array}{l}0.285 \\
(0.64)\end{array}$ & $\begin{array}{l}0.169 \\
(0.71)\end{array}$ & $\begin{array}{l}0.759 \\
(1.45)\end{array}$ & $\begin{array}{l}0.891 \\
(1.76)\end{array}$ & $\begin{array}{l}1.770 * * * \\
(0.48)\end{array}$ & $\begin{array}{l}1.764^{* * * *} \\
(0.50)\end{array}$ & $\begin{array}{l}0.693 \\
(0.77)\end{array}$ & $\begin{array}{l}1.249 \\
(0.85)\end{array}$ \\
\hline Medium-low tech industry & $\begin{array}{l}0.087 \\
(0.38)\end{array}$ & $\begin{array}{l}0.194 \\
(0.40)\end{array}$ & $\begin{array}{l}-0.584 \\
(0.50)\end{array}$ & $\begin{array}{l}-0.344 \\
(0.53)\end{array}$ & $\begin{array}{l}0.358 \\
(0.74)\end{array}$ & $\begin{array}{l}0.394 \\
(0.77)\end{array}$ & $\begin{array}{l}0.811 \\
(1.11)\end{array}$ & $\begin{array}{l}0.830 \\
(1.16)\end{array}$ & $\begin{array}{l}1.345^{* * *} \\
(0.53)\end{array}$ & $\begin{array}{l}1.397^{* * * *} \\
(0.53)\end{array}$ & $\begin{array}{l}0.672 \\
(0.66)\end{array}$ & $\begin{array}{l}0.885 \\
(0.67)\end{array}$ \\
\hline Year & Yes & Yes & Yes & Yes & Yes & Yes & Yes & Yes & Yes & Yes & Yes & Yes \\
\hline Country & Yes & Yes & Yes & Yes & Yes & Yes & Yes & Yes & Yes & Yes & Yes & Yes \\
\hline Constant & $\begin{array}{l}-19.528 \\
(67.75)\end{array}$ & $\begin{array}{l}-31.948 \\
(69.42)\end{array}$ & $\begin{array}{l}-19.421 \\
(68.61)\end{array}$ & $\begin{array}{l}-28.399 \\
(70.05)\end{array}$ & $\begin{array}{l}-39.535 \\
(117.34)\end{array}$ & $\begin{array}{l}-59.424 \\
(125.97)\end{array}$ & $\begin{array}{l}-24.993 \\
(120.59)\end{array}$ & $\begin{array}{l}-32.002 \\
(126.61)\end{array}$ & $\begin{array}{l}-68.307 \\
(66.13)\end{array}$ & $\begin{array}{l}-78.082 \\
(66.81)\end{array}$ & $\begin{array}{l}-67.095 \\
(66.17)\end{array}$ & $\begin{array}{l}-76.554 \\
(67.52)\end{array}$ \\
\hline Observations & 759 & 759 & 759 & 759 & 734 & 734 & 734 & 734 & 771 & 771 & 771 & 771 \\
\hline Pseudo $R^{2}$ & 0.090 & 0.118 & 0.111 & 0.132 & 0.089 & 0.113 & 0.107 & 0.133 & 0.099 & 0.107 & 0.111 & 0.119 \\
\hline LR chi2 & $95.046^{* * *}$ & $123.961^{* * *}$ & $116.849^{* * *}$ & $138.413^{* * *}$ & 33.489 & 42.557 & 40.370 & $49.852 *$ & $96.098^{* * *}$ & $104.221^{* * *}$ & $108.070^{* * *}$ & $116.038^{* * *}$ \\
\hline
\end{tabular}

Notes: Standard errors in parentheses. ${ }^{*} p<0.1,{ }^{* *} p<0.05,{ }^{* * *} p<0.01$. 


$$
\begin{aligned}
& R \& D_{i, t}=\beta_{0}+\beta_{1} Z_{i . t-1}+\varepsilon_{i . t} \\
& R \& D_{i, t}=\beta_{0}+\beta_{1} \text { Host }_{i . t-1}+\beta_{2} Z_{i . t-1}+\varepsilon_{i . t} \\
& R \& D_{i, t}=\beta_{0}+\beta_{1} \text { Home }_{i . t-1}+\beta_{2} Z_{i . t-1}+\varepsilon_{i . t} \\
& R \& D_{i, t}=\beta_{0}+\beta_{1} \text { Host }_{i . t-1}+\beta_{2} \text { Home }_{i . t-1}+\beta_{3} Z_{i . t-1}+\varepsilon_{i . t}
\end{aligned}
$$

where Manufacturing ${ }_{i, t}$, Sales and service ${ }_{i, t}$, and $R \& D_{i, t}$ represent whether the motivation of Chinese OFDI to EU for industry i is manufacturing, sales and service, or R\&D respectively in year t. Host $t_{i .} t-1$ is the industry level factors for EU (host countries) for industry $\mathrm{i}$ in year $\mathrm{t}-1$, Home $_{i . t-1}$ is the industry level factors for China (home country) for industry $\mathrm{i}$ in year $\mathrm{t}-1$, and $Z_{i . t-1}$ indicates controls for industry $\mathrm{i}$ in year $\mathrm{t}-1$.

Table 3 presents the estimation results of the three logistic regressions, with model A for manufacturing OFDI, model B for sales and service and model C for R\&D. The significance of model B is associated with the underrepresented observations of firms without sales and service motivation. Further analysis is conducted below to address this issue.

As already discussed, the logistic regressions address the three motivations of OFDI separately. However, each individual investment may have multiple motivations i.e. a firm may invest for both manufacturing and R\&D. Logistic regression alone is not sufficient to analyze the interactions between such different investment motivations. Therefore, we pool the three types of motivations and conduct further multinomial logistic regression.

Table 4 presents all possible combinations of the three types of investment motivations. The number of observations for some sets is inadequate for a reliable analysis. Chinese OFDI with only manufacturing motivation, only R\&D motivation and both manufacturing and R\&D motivation are clearly underrepresented. Consistent with Plechero and Chaminade (2013), we solve this issue by aggregating the underrepresented categories into wider groupings and isolating sales and service. OFDI which focuses 'only' on sales and service tends to be much less embedded in the local industrial context than that which also addresses either R\&D or manufacturing. Thus, the factors which stimulate investment in a sales office could be expected to be markedly different to those for investments that combine sales with a factory and/or an R\&D lab. We therefore combine 3, 5, 6 and 7 into one category: 'at least' R\&D (R\&D-oriented). Set 1 and 4 are grouped into another category, 'at least' manufacturing (manufacturing-oriented), while set 2 is retained alone as 'only' sales and service (market-oriented). Our new categories of investment motivation are presented in Table 5. All three have sufficient observations for analysis, while also having one defining motivation.

The results of our multinomial logistic regression are reported in Table 6. As indicated in Table B, the dependent variable is a multicategorical one. Using the method developed by Hausman and McFadden (1984), the model has been tested to satisfy the assumption of independence from irrelevant alternatives (IIA), which requires that the choice between any two categories in the dependent variable is not related to other categories.

\section{Findings and discussion}

\subsection{Chinese and host EU industry-level factors and OFDI motivation}

The above analysis confirms our key point that variations in FDI motivation and sectoral differences are important to understanding investment patterns. Specifically, when we include the variables related to industrial characteristics of Chinese and EU countries in the logistic regression, the explanatory power of most of the control variables diminishes significantly, while the models as a whole become more significant, especially for R\&D motivation (models A4, B4 and C4). This implies that the observed differences across types of OFDI motivations can, to a large extent, be explained by industrial characteristics in the home and host countries.

In terms of our key findings, with respect to industry-level factors in the EU host country, the coefficient for industry R\&D intensity is positive and significant for R\&D oriented motivations in Model C2. When industry-level variables are introduced, it loses significance in Model C4. This result is confirmed in the multinomial logistic regression (models D2 and D4) where investments motivated by $R \& D$ are attracted to countries in which the industry has higher R\&D intensity, in contrast to investments in manufacturing (but not sales and service). Thus, Hypothesis 1a is partially supported.

The results suggest that EU sectoral labor productivity (EU industry productivity) has positive and significant effects on FDI with

Table 4

Combinations of the three types of investment motivations.

\begin{tabular}{ll}
\hline Motivations & Number of investments \\
\hline 1 only manufacturing & 27 \\
2 only sales and service & 319 \\
3 only R\&D & 9 \\
4 only manufacturing and sales and service & 192 \\
5 only manufacturing and R\&D & 16 \\
6 only sales and service and R\&D & 81 \\
7 three types of motivations & 150 \\
Total & 794 \\
\hline
\end{tabular}


Table 5

The dependent variable of the multinomial logistic regression.

\begin{tabular}{ll}
\hline Motivations & Number of investments \\
\hline 1 At least manufacturing (manufacturing oriented) & 219 \\
2 Only sales and service (market oriented) & 319 \\
3 At least R\&D (R\&D oriented) & 256 \\
Total & 794 \\
\hline
\end{tabular}

sales and service motivation, compared to the other two motivations (models D2 and D4). Models A3 and A4 also suggest a significantly negative effect of EU sectoral labor productivity on investment with manufacturing motivation. Thus, Hypothesis 2 ais not supported. Rather than encouraging investment in manufacturing, high EU labor productivity discourages it and rather encourages sales-oriented FDI. This result is counter-intuitive. One explanation could be that countries with high labor productivity also tend to have higher wages and thus greater market potential. This could cause investors in these locations to favor sales, rather than (potentially expensive) manufacturing, a linkage further supported by the negative relationship noted below between GDP per capita and manufacturing-oriented FDI. As highlighted by Cushman (1987), the interaction between productivity and wages is vital to explaining FDI. Although certain EU industries are very productive, if wage levels are much higher than in China, they will still represent unattractive manufacturing centers.

Finally, the importance of an industry in the domestic manufacturing economy (EU relevance of the sector) is positively and significantly associated with OFDI in manufacturing (models A2 and A4). Models D2 and D4 also confirm that industries which are important to the local productive economy tend to attract manufacturing or R\&D oriented Chinese investments, rather than sales and service, thus Hypothesis 4ais supported.

High growth industries (EU sectoral growth) were more likely to attract Chinese firms motivated by manufacturing, rather than sales and service and R\&D (models D2 and D4). Thus, Hypothesis 4bis partly supported, although we did not find sales and service motivated FDI to be attracted by high growth industries. In contrast, the logistic regressions suggest a negative relationship between the two (models B2 and B4). One possible explanation for this counter-intuitive result is that rapidly growing sectors have high levels of sector-specific knowledge, where Chinese manufacturers might not be experienced enough to risk overseas market-oriented investments. Investments in manufacturing, on the other hand, could involve the acquisition of strategic assets - in the form of knowledge on new processes and customer needs - from these high growth contexts. Certainly, these results call for further investigation.

On the home country side, our findings suggest that Chinese firms from R\&D intensive industries are more likely to be motivated by R\&D, than sales and service or manufacturing in their OFDI into the EU(models B3, B4, C3, C4, D3 and D4). Thus, Hypothesis 1b is supported.

We also find that both sectoral labor productivity (Chinese industry labor productivity) and productivity growth over time (Chinese industry productivity growth) have positive and significant effects on OFDI with R\&D motivation, compared with the other two (models A3, A4, B3, B4, C3, C4, D3 and D4). Thus, Hypothesis 2b is partially supported. In contrast to Yan et al.' s (2018) findings using firm level data, companies from industries with high domestic labor productivity were not more likely to invest in sales and service or manufacturing. Rather, they are more likely to invest in R\&D. Yan et al. (2018) highlight that productive firms have fewer financial constraints and more resources for investment. Perhaps, in this context, firms have greater interest in more long-term investments in R\&D in the EU, rather than short-term sales and service. With extensive productive capacity in China, they may not be motivated to undertake new manufacturing investments in more expensive foreign countries.

In relation to sectoral investment levels in China (Chinese industry investment propensity), the coefficient is positive and significant for manufacturing motivation in both the logistic regressions (models A3 and A4) and multinomial logistic regression (models D3 and D4). This indicates that, in contrast to sales and service or R\&D motivation, Chinese firms operating in industries with high levels of domestic manufacturing investment, also tend to invest in manufacturing in the EU. Thus, H3 is partially supported, although domestic investment in manufacturing does not encourage OFDI in sales. One possible explanation for the latter counter-intuitive result is that, domestic institutional constraints, such as lack of skilled staff, unfavorable domestic markets (Gaur et al., 2018), or internal barriers to inter-provincial investment (Huang, Zhang, and Angelino, 2017), may encourage Chinese companies which have finance available for investment, to expand their manufacturing capacity elsewhere. In addition, firms in sectors with high levels of domestic investment may have mature and advanced production capability, which can be leveraged when investing abroad in similar activities. Finally, capital intensive industries, like automobiles and cement, may also be associated with relatively high transport costs, which have been shown to favor FDI in manufacturing (Daniels \& Ruhr, 2014). Together, these factors could explain the observed tendency for firms in industries with high levels of domestic investment to favor investment in production in the EU, rather than sales and service or R\&D.

\subsection{Industry and country-level differences in OFDI motivation}

In model A1 and C1, the coefficients for high-technology industries are positive and significant for manufacturing and R\&D oriented firm motivations. When introducing the industry-level variables, it loses significance for R\&D, while becoming more significant for manufacturing (models A4 and C4). The results, to some extent, are confirmed in the multinomial logistic regression in Table 6. Together these findings suggest that compared with firms in low-technology industries (the baseline dummy) Chinese firms in high- 
Table 6

Multinomial logistic regression.

\begin{tabular}{|c|c|c|c|c|c|}
\hline & & (1) & (2) & (3) & (4) \\
\hline & & ModelD1 & ModelD2 & ModelD3 & ModelD4 \\
\hline \multirow{40}{*}{$\begin{array}{l}\text { Manufacturing } \\
\text { in contrast to } \\
\text { Sales and service }\end{array}$} & \multirow[t]{2}{*}{ EU industry R\&D intensity } & & \multirow{2}{*}{\multicolumn{2}{|c|}{$\begin{array}{l}-0.046^{*} \\
(0.02)\end{array}$}} & -0.024 \\
\hline & & & & & $(0.03)$ \\
\hline & \multicolumn{2}{|l|}{ EU industry productivity } & \multirow{2}{*}{\multicolumn{2}{|c|}{$\begin{array}{l}-0.130 * * \\
(0.06)\end{array}$}} & $-0.160 * *$ \\
\hline & & & & & $(0.07)$ \\
\hline & \multicolumn{2}{|l|}{ EU relevance of the sector } & \multirow{2}{*}{\multicolumn{2}{|c|}{$\begin{array}{l}0.094^{* * *} \\
(0.03)\end{array}$}} & 0.041 \\
\hline & & & & & $(0.03)$ \\
\hline & \multirow[t]{2}{*}{ EU sectoral growth } & & \multicolumn{2}{|l|}{$0.019^{*}$} & $0.024 * *$ \\
\hline & & & $(0.01)$ & & $(0.01)$ \\
\hline & \multirow[t]{2}{*}{ Chinese industry R\&D intensity } & & & 0.806 & 0.404 \\
\hline & & & & $(0.69)$ & $(0.74)$ \\
\hline & \multirow[t]{2}{*}{ Chinese industry labor productivity } & & & 0.024 & 0.049 \\
\hline & & & & $(0.06)$ & $(0.06)$ \\
\hline & \multirow{2}{*}{ Chinese industry productivity growth } & & & -0.012 & 0.005 \\
\hline & & & & $(0.04)$ & $(0.04)$ \\
\hline & Chinese industry investment propensity & & & $0.153^{* * *}$ & $0.136^{* * *}$ \\
\hline & & & & $(0.03)$ & $(0.03)$ \\
\hline & Host GDP & 28.293 & 32.013 & 26.344 & 28.755 \\
\hline & & $(18.91)$ & $(19.50)$ & $(19.51)$ & $(19.93)$ \\
\hline & Host GDP per capita & $-40.343^{* *}$ & $-44.091^{* *}$ & $-38.401^{*}$ & $-40.681^{*}$ \\
\hline & & $(19.78)$ & $(20.38)$ & $(20.39)$ & $(20.80)$ \\
\hline & Agglomeration & $0.086^{* * *}$ & $0.095^{* * *}$ & $0.099 * * *$ & $0.104 * * *$ \\
\hline & & $(0.03)$ & $(0.03)$ & $(0.03)$ & $(0.03)$ \\
\hline & Encouraged industries & $-0.678^{*}$ & $-0.955^{* *}$ & 0.038 & -0.282 \\
\hline & & $(0.39)$ & $(0.40)$ & $(0.45)$ & $(0.47)$ \\
\hline & Prioritized industries & 0.087 & 0.335 & 0.253 & 0.547 \\
\hline & & $(0.58)$ & $(0.60)$ & $(0.61)$ & $(0.62)$ \\
\hline & Government participation & $7.273 * * *$ & $9.100 * *$ & 2.397 & 4.148 \\
\hline & & $(2.81)$ & $(3.57)$ & $(3.43)$ & (3.99) \\
\hline & Industry competition intensity & 0.200 & 0.481 & $4.318^{* *}$ & $3.647^{*}$ \\
\hline & & (1.95) & $(1.98)$ & $(2.13)$ & $(2.17)$ \\
\hline & High-tech industry & 0.683 & $2.246^{* * *}$ & -0.087 & 1.358 \\
\hline & & $(0.46)$ & $(0.70)$ & $(0.95)$ & (1.13) \\
\hline & Medium-high tech industry & 0.018 & 0.412 & $-1.705^{* *}$ & -0.957 \\
\hline & & $(0.38)$ & $(0.43)$ & $(0.78)$ & $(0.86)$ \\
\hline & Medium-low tech industry & 0.387 & 0.430 & -0.623 & -0.506 \\
\hline & & $(0.43)$ & $(0.45)$ & $(0.56)$ & $(0.60)$ \\
\hline & Year & Yes & Yes & Yes & Yes \\
\hline & Country & Yes & Yes & Yes & Yes \\
\hline & Constant & 49.182 & 41.264 & 54.341 & 47.147 \\
\hline & & $(2061.41)$ & $(1806.95)$ & $(2112.48)$ & $(2945.18)$ \\
\hline Manufacturing & EU industry R\&D intensity & & $-0.066^{* * *}$ & & $-0.043^{*}$ \\
\hline in contrast to & & & $(0.02)$ & & $(0.03)$ \\
\hline $\mathrm{R} \& \mathrm{D}$ & EU industry productivity & & -0.064 & & -0.047 \\
\hline & & & $(0.06)$ & & $(0.07)$ \\
\hline & EU relevance of the sector & & 0.043 & & -0.009 \\
\hline & & & $(0.03)$ & & $(0.03)$ \\
\hline & EU sectoral growth & & $0.026^{* *}$ & & $0.029 * *$ \\
\hline & & & $(0.01)$ & & $(0.01)$ \\
\hline & Chinese industry $R \& D$ intensity & & & -0.804 & -0.512 \\
\hline & & & & $(0.71)$ & $(0.78)$ \\
\hline & Chinese industry labor productivity & & & -0.079 & -0.080 \\
\hline & & & & $(0.07)$ & $(0.07)$ \\
\hline & Chinese industry productivity growth & & & $-0.071^{*}$ & $-0.077^{*}$ \\
\hline & & & & $(0.04)$ & $(0.04)$ \\
\hline & Chinese industry investment propensity & & & $0.121^{* * *}$ & $0.119 * * *$ \\
\hline & & & & $(0.03)$ & $(0.03)$ \\
\hline & Host GDP & -5.144 & -2.533 & -4.741 & -2.357 \\
\hline & & $(17.65)$ & (18.19) & $(17.96)$ & (18.59) \\
\hline & Host GDP per capita & -0.484 & -3.910 & -0.997 & -3.825 \\
\hline & & $(18.55)$ & $(19.10)$ & $(18.88)$ & $(19.48)$ \\
\hline & Agglomeration & $0.064 *$ & $0.086^{* *}$ & $0.082 * *$ & $0.088 * *$ \\
\hline & & $(0.03)$ & $(0.04)$ & $(0.04)$ & $(0.04)$ \\
\hline & Encouraged industries & -0.442 & -0.689 & 0.013 & -0.112 \\
\hline & & $(0.40)$ & $(0.44)$ & $(0.47)$ & $(0.51)$ \\
\hline & Prioritized industries & 0.803 & 0.952 & 0.983 & 1.158 \\
\hline & & $(0.79)$ & $(0.81)$ & $(0.81)$ & $(0.82)$ \\
\hline & Government participation & -0.903 & 2.507 & -2.079 & 0.238 \\
\hline
\end{tabular}




\begin{tabular}{|c|c|c|c|c|c|}
\hline & & (1) & (2) & (3) & (4) \\
\hline & & ModelD1 & ModelD2 & ModelD3 & ModelD4 \\
\hline \multirow{50}{*}{$\begin{array}{l}\text { Sales and service } \\
\text { in contrast to } \\
\text { R\&D }\end{array}$} & \multirow{3}{*}{ Industry competition intensity } & $(2.58)$ & $(3.55)$ & (3.33) & $(4.03)$ \\
\hline & & 0.681 & 0.453 & $4.101 *$ & 3.797 \\
\hline & & $(2.11)$ & $(2.13)$ & $(2.29)$ & $(2.33)$ \\
\hline & \multirow{2}{*}{ High-tech industry } & $-1.795^{* * *}$ & -0.280 & -0.534 & -0.121 \\
\hline & & $(0.59)$ & $(0.78)$ & $(1.04)$ & $(1.23)$ \\
\hline & Medium-high tech industry & $-1.733^{* * *}$ & $-1.404^{* *}$ & $-1.737^{* *}$ & $-1.801 *$ \\
\hline & \multirow[t]{2}{*}{ Medium-low tech industry } & $\begin{array}{l}(0.53) \\
-1.092^{*}\end{array}$ & $\begin{array}{l}(0.57) \\
-1.038^{*}\end{array}$ & $\begin{array}{l}(0.89) \\
-1.027\end{array}$ & $\begin{array}{l}(0.98) \\
-1.134\end{array}$ \\
\hline & & $(0.58)$ & $(0.59)$ & $(0.72)$ & $(0.75)$ \\
\hline & Year & Yes & Yes & Yes & Yes \\
\hline & Country & Yes & Yes & Yes & Yes \\
\hline & \multirow[t]{2}{*}{ Constant } & 73.269 & 75.734 & 74.718 & 74.109 \\
\hline & & (4146.98) & $(3673.73)$ & $(4301.23)$ & $(5782.90)$ \\
\hline & EU industry R\&D intensity & & $\begin{array}{l}-0.021 \\
(0.02)\end{array}$ & & $\begin{array}{l}-0.018 \\
(0.02)\end{array}$ \\
\hline & \multirow{2}{*}{ EU industry productivity } & & 0.066 & & $0.112^{*}$ \\
\hline & & & $(0.05)$ & & $(0.06)$ \\
\hline & EU relevance of the sector & & $\begin{array}{l}-0.051^{* *} \\
(0.03)\end{array}$ & & $\begin{array}{l}-0.050^{*} \\
(0.03)\end{array}$ \\
\hline & \multirow[t]{2}{*}{ EU sectoral growth } & & 0.007 & & 0.005 \\
\hline & & & $(0.01)$ & & $(0.01)$ \\
\hline & Chinese industry R\&D intensity & & & $-1.610^{* *}$ & -0.916 \\
\hline & Chinese industry labor productivity & & & -0.103 & $-0.129^{*}$ \\
\hline & \multirow[t]{2}{*}{ Chinese industry productivity growth } & & & -0.060 & $-0.082^{* *}$ \\
\hline & & & & $\begin{array}{l}(0.04) \\
-0.032\end{array}$ & $\begin{array}{l}(0.04) \\
-0.017\end{array}$ \\
\hline & Chinese industry investment propensity & & & $\begin{array}{l}-0.032 \\
(0.03)\end{array}$ & $(0.03)$ \\
\hline & \multirow[t]{2}{*}{ Host GDP } & $-33.436^{*}$ & $-34.546^{*}$ & -31.086 & -31.112 \\
\hline & & (19.81) & $(20.08)$ & (19.94) & $(20.27)$ \\
\hline & \multirow[t]{2}{*}{ Host GDP per capita } & $39.859^{*}$ & $40.182^{*}$ & $37.404 *$ & $36.856^{*}$ \\
\hline & & $(20.70)$ & $(20.97)$ & $(20.85)$ & (21.17) \\
\hline & \multirow[t]{2}{*}{ Agglomeration } & -0.022 & -0.009 & -0.017 & -0.015 \\
\hline & & $(0.03)$ & $(0.04)$ & $(0.03)$ & $(0.04)$ \\
\hline & \multirow{2}{*}{ Encouraged industries } & 0.236 & 0.266 & -0.025 & 0.171 \\
\hline & & $(0.41)$ & $(0.42)$ & $(0.45)$ & $(0.48)$ \\
\hline & \multirow{2}{*}{ Prioritized industries } & 0.717 & 0.617 & 0.730 & 0.611 \\
\hline & & $(0.76)$ & $(0.77)$ & $(0.79)$ & $(0.80)$ \\
\hline & \multirow[t]{2}{*}{ Government participation } & $-8.175^{* * *}$ & $-6.593^{* *}$ & -4.476 & -3.909 \\
\hline & & $(2.58)$ & $(3.32)$ & $(3.05)$ & $(3.69)$ \\
\hline & Industry competition intensity & 0.481 & -0.028 & -0.217 & 0.149 \\
\hline & & $(1.86)$ & $(1.93)$ & $(2.12)$ & $(2.16)$ \\
\hline & High-tech industry & $-2.478^{* * *}$ & $-2.526^{* * *}$ & -0.447 & -1.479 \\
\hline & & $(0.56)$ & $(0.71)$ & $(1.00)$ & $(1.16)$ \\
\hline & Medium-high tech industry & $-1.751^{* * *}$ & $-1.816^{* * *}$ & -0.032 & -0.844 \\
\hline & & $(0.51)$ & $(0.53)$ & $(0.85)$ & $(0.93)$ \\
\hline & Medium-low tech industry & $-1.479 * * *$ & $-1.467^{* * *}$ & -0.404 & -0.628 \\
\hline & & $(0.56)$ & $(0.57)$ & $(0.70)$ & $(0.72)$ \\
\hline & Year & Yes & Yes & Yes & Yes \\
\hline & Country & Yes & Yes & Yes & Yes \\
\hline & Constant & 24.087 & 34.470 & 20.377 & 26.962 \\
\hline & & $(3598.66)$ & $(3199.00)$ & $(3747.04)$ & (4977.02) \\
\hline & Observations & 794 & 794 & 794 & 794 \\
\hline & Pseudo $R^{2}$ & 0.150 & 0.168 & 0.173 & 0.184 \\
\hline & chi2 & $258.146^{* * *}$ & $289.224^{* * * *}$ & $298.694 * * *$ & $318.154^{* * *}$ \\
\hline
\end{tabular}

Notes: Standard errors in parentheses. ${ }^{*} p<0.1,{ }^{* *} p<0.05,{ }^{* * *} p<0.01$.

technology industries are more motivated to invest in manufacturing and $R \& D$, than sales and service.

The significant coefficient of medium-high-technology industries and medium-low-technology industries for R\&D motivation (models C1, C2 and D), indicates that, in contrast to low-technology industries, OFDI by firms in these two sectors are more motivated by R\&D than manufacturing, or sales and service. Thus, firms in higher technology sectors are more likely to invest in R\&D and manufacturing, while those in lower technology sectors are more likely to engage in sales and service OFDI, although those in medium tech industries seem more motivated by R\&D than manufacturing.

The results confirm that, in line with findings in aggregate studies, market size impacts on OFDI in EU manufacturing (models A1A4). However, the negative and significant coefficient of GDP per capita in the logistic regressions (models A1-A4), indicates that 
market affluence discourages such investment. This finding is generally confirmed in the multinomial logistic regression (model D) where manufacturing subsidiaries, in contrast to sales and service (but not R\&D), are less attracted to countries with higher income per capita. The finding is unsurprising, given that wealthy countries have higher wages, which have been found to discourage FDI in Europe (Barrell \& Pain, 1999; Ford \& Strange, 1999). Efficiency-seeking or manufacturing-oriented FDI may be particularly susceptible to this effect.

With regard to national agglomeration effects, we found that cumulative existing Chinese investments in a country are a more important stimulant for Chinese firms investing overseas in manufacturing than sales and service and R\&D (models A4 and D1-D4). In contrast, the negative and significant coefficients in Models B3 and B4 show that agglomeration effects may act as a disincentive to sales and service-oriented investment. This suggests that for firms with manufacturing motivation, agglomeration forces dominate over the dispersion forces, while for sales and service motivation the opposite is the case. The agglomeration of productive activities is consistent with the findings of Crescenzi et al. (2016) on EMNE' s FDI in European regions. The failure to confirm agglomeration effects for R\&D activities is surprising and to some extent contrary to the latter' s findings; however, they found that investments from EMNEs in $R \& D$ exhibit agglomeration only with investments in the same function at sub-national level (op.cit.), while we test for agglomeration for all investments at national level.

The negative and significant coefficients for competition intensity in Models B3 and B4 show that firms in more competitive Chinese sectors are less likely to invest in sales and service in Europe. This result is confirmed in the multinomial logistic regressions (models D3 and D4), where industries with high competition intensity in China are less likely to invest in sales and service, in contrast to manufacturing (but not R\&D).

In relation to industries where OFDI is encouraged by the Chinese government, the negative and significant coefficients in Models A1 and A2 indicate that policy support acts as a disincentive for Chinese firms investing overseas in manufacturing. This result is confirmed in the multinomial logistic regression (models D1 and D2), where manufacturing-oriented investments from such industries are less likely, in contrast to sales and service (but not R\&D). However, the coefficients for prioritized industries are insignificant in all models.

Finally, with regard to government participation, the coefficients are positive and significant for manufacturing-oriented motivation in Models A1 and A2 and for R\&D oriented motivation in Model C1. These findings are confirmed to some extent in the multinomial logistic regressions. Chinese firms in industries with high levels of government participation are more motivated to invest in manufacturing, than sales and service (but not R\&D). In addition, from models D1 and D2, we can see that Chinese firms in industries with high government participation are more motivated to invest in R\&D, than sales and service (but not manufacturing). These findings suggest that Chinese firms in industries with strong state involvement tend to invest overseas in manufacturing and $R \& D$, rather than sales and service. Taken together, our results on the impacts of sectoral variance in government intervention suggest that Chinese industrial policies do indeed have an important influence on firms' s; FDI. Further research is required to develop investigation on these interactions.

\section{Conclusions and avenues for further work}

In this paper, we have sought to identify the extent to which industrial characteristics in both China and EU host countries can be seen to stimulate Chinese OFDI with different motivations. Our analysis confirms that certain industrial characteristics are associated with specific investment motivations, underlining one of the key points of this paper: that exploring FDI in aggregate terms obscures important differences within FDI flows. Fig. 4 summarizes the key findings of our paper.

In terms of the key industry level characteristics which we explored, firms from Chinese industries with high domestic labor productivity were found to be more likely to engage in R\&D-oriented OFDI, while more productive EU host country industries were more likely to attract FDI oriented towards sales and services, rather than manufacturing. Thus, home and host country productivity seem to stimulate FDI with different motivations, the impacts of which on both economies are also likely to differ (Driffield \& Love, 2007; Knoerich, 2017). These findings support our proposition that the linkages between FDI and sectoral productivity are more complex than is assumed in much of the literature, which has focused on spillover effects, usually assumed to be unidirectional

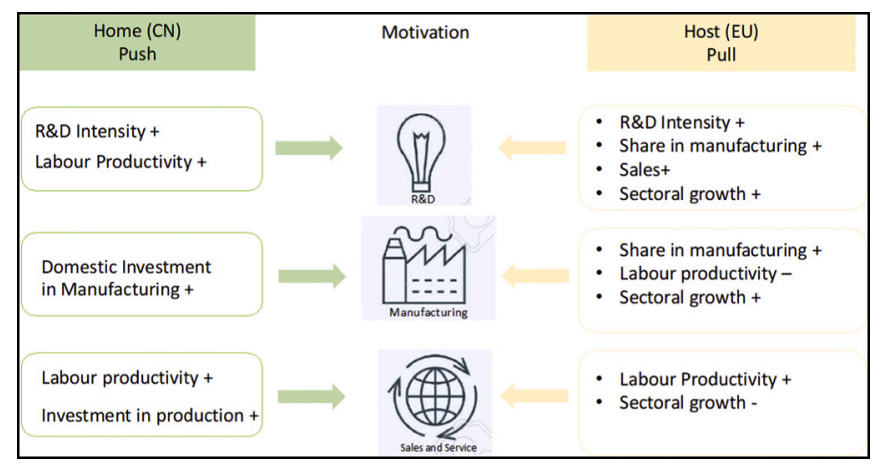

Fig. 4. Key contributions to understanding of meso level interactions with FDI. 
(Knoerich, 2017). Our results suggest that more detailed analyses of these interactions could be informative.

We also examined the impact of domestic investment levels on OFDI and found that firms in industries with higher investment in production in China were more likely to engage in manufacturing-oriented investment in the EU, rather than sales and services or R\&D. This result indicates that higher levels of domestic manufacturing investment motivate firms to also invest in manufacturing activities abroad, rather than market-seeking investment, as one might expect. These findings supplement prior research exploring the impact of IFDI on host country investment, which tended to assume that the effects are unidirectional (from FDI to host country investment) (Kamaly, 2014; Rath \& Bal, 2014). Investment levels in the source country also seem to have an impact on OFDI.

Sectors important to the local productive economy were found to attract both manufacturing and R\&D oriented investments, suggesting that in more mature, well established European industries, Chinese investors were more motivated by technology and know-how, than by the market - i.e. classic 'strategic-asset seeking' FDI (Dunning, 1993).

Finally, high growth industries in the EU were found to attract manufacturing-oriented Chinese OFDI, rather than sales and service. Perhaps high growth industries are not yet mature enough to attract market-oriented FDI, or Chinese firms are not yet experienced enough to venture into such high growth markets. In conducting this work, we identified no substantial prior research on the relationship between either the economic weight of industries, or their growth rates, on FDI. Our findings suggest that linkages exist, although more research is certainly needed to better identify these across time and space.

In terms of differences between types of industries, we find - as expected - that Chinese firms in higher tech sectors are more likely to engage in $R \& D$ and manufacturing FDI, while those from low tech sectors are more focused on FDI for sales and services. R\&D intensity within an industry in both China and the EU is associated with higher levels of R\&D motivated investment. This result is consistent with Lu et al.' s (2011) study on Chinese OFDI, which found strategic-asset seeking FDI to be more prevalent in more technologically advanced companies and sectors. We also find that Chinese government policy impacts on FDI motivations. Firms in 'encouraged' s; industries are more likely to engage in sales and service, rather than manufacturing, while those in industries with higher levels of government participation tend to invest overseas in manufacturing and $\mathrm{R} \& \mathrm{D}$, rather than sales and service.

Finally, we find greater agglomeration effects for production related FDI, which tends to cluster more within nations than other types of investments. This is to some extent contradictory to Crescenzi et al. (2016), who note agglomeration effects for R\&D investments. At the same time, it is consistent with the long-standing literature on agglomeration, that underlines how companies can benefit from clustering thanks to both the traditional Marshallian externalities and different forms of collective action (Disdier \& Mayer, 2004; Schmitz, 2000).

Overall, the analysis in this paper demonstrates that adopting an 'industry-based' s; view of FDI can highlight supplementary relationships between FDI and source and host industry-level factors, obscured by more firm- or institutional-based approaches. There is no question that these other two approaches have provided many useful insights. However our work shows that both the motivation for FDI and the sector in which it takes place do matter, such that the industrial characteristics of both host and home countries interact with FDI motivation. Given these findings, drawing conclusions about FDI determinants across aggregate flows may risk erroneous conclusions.

Our findings confirm the view that future research on FDI flows needs to engage with the 'industry-based view' and its implications for the heterogeneity of FDI, especially across motivations and source and host countries. Almost 30 years after Dunning highlighted the importance of differentiating between the underlying motives of FDI, integrating these variances more effectively into IB research seems to us to be long overdue.

In terms of the policy debate, we confirm the perception that more technologically advanced sectors in China are motivated by European technology (R\&D) and know how (manufacturing) when investing in the EU (EP., 2018; Knoerich \& Miedtank, 2018; Nicolas, 2014). Clearly, Volvo, Cifa and Kuka are not exceptions, but indicative of a broader trend amongst Chinese technology-based companies. This is not peculiar to Chinese companies. Prior work underlines that firms in high tech sectors tend to be intrinsically more internationally oriented (Boter \& Holmquist, 1996; Curran \& Thorpe, 2013). Nevertheless, as noted in the introduction, such investments have raised concerns about the potential loss of critical technology and knowledge. These fears will likely intensify postCOVID, as the EU seeks to maximize its 'strategic autonomy' (CEC, 2020). Investors need to be mindful of this and ensure the twoway flow of expertise in order to maximize synergies between Chinese headquarters and European subsidiaries.

From an EU perspective, job creation and retention are key policy objectives as it emerges from the financial crisis and the pandemic (CEC, 2020). A strong manufacturing sector could clearly be supportive of these objectives. Our findings indicate that Chinese manufacturing investment in Europe is particularly attracted to high tech sectors, as well as sectors which are important to the local economy and have high growth rates. At the same time, Chinese companies from industries with high levels of domestic investment, tend to also favor investing in manufacturing in Europe. Focusing investment promotion actions on such sectors could help to secure future investment flows.

From a Chinese perspective, our research confirms that firms in sectors with high levels of R\&D investment and high labor productivity tend to invest in R\&D related activities abroad. Thus, policy support for increased R\&D investment and productivity can stimulate firms to widen their technological expertise, through overseas R\&D investments. In addition, higher domestic investment in production would help Chinese firms to secure economics of scale, not only at national level, but also at international level, in that advanced sectoral production capability can be leveraged when investing abroad in similar activities. Thus, policies aiming at advancing domestic production capability could also be helpful in stimulating OFDI. 
In terms of the limitations of our study, while we focus on the sectoral factors which we consider to be most likely to affect FDI motivation, there are certainly other home and host level factors which could be explored in future work. In addition, our analysis aggregates greenfield and non-greenfield investments, although mode of entry may also be an important variable for consideration. Further investigations on the interactions between entry modes of FDI, its underlying motivation and industry level factors could certainly yield interesting insights.

Another key limitation of our study is that it has focused on one source country - China - which, as many scholars have pointed out, has quite specific characteristics (Buckley et al., 2007; Buckley et al., 2018; Knoerich \& Miedtank, 2018; Ramamurti \& Hillemann, 2018) and on one destination region - the EU. While we would expect that other home and host countries would also exhibit differences in investment motivations depending on the sectoral characteristics of their economies, further research is certainly required to explore these interactions.

Finally, in order to focus our study and, particularly, to limit relevant industrial characteristics, we only consider manufacturing industry. There is a need for more research which engages with the impact of this meso-level on FDI, across a broader range of countries and sectors. We hope that this paper can contribute to this objective by providing a firm theoretical and empirical framework for further work.

\section{Acknowledgements}

This paper was funded by the National Natural Science Foundation of China ( $\left.{ }^{\circ} 71872168, \mathrm{n}^{\circ} 71472173\right)$.

\section{Appendix A}

Table A

Sub-sectoral distribution of Chinese OFDI in EU in manufacturing sectors, 2006-2015.

\begin{tabular}{|c|c|c|c|c|}
\hline Sub-sector & $\begin{array}{l}\text { N. of } \\
\text { investments }\end{array}$ & $\begin{array}{l}\text { Percentage } \\
(\%)\end{array}$ & $\begin{array}{l}\text { Status on prioritized industries in } \\
\text { Eleventh Five-Year Plan }(2006-2010)\end{array}$ & $\begin{array}{l}\text { Status on prioritized industries in } \\
\text { Twelfth Five-Year Plan (2011-2015) }\end{array}$ \\
\hline $\begin{array}{l}\text { Electrical machinery and apparatus, } \\
\text { n.e.c. }{ }^{2}\end{array}$ & 181 & 22.8 & $\mathrm{P}$ & $\mathrm{P}$ \\
\hline Machinery and equipment, n.e.c. ${ }^{2}$ & 167 & 21.0 & $\mathrm{E}$ & $\mathrm{E} / \mathrm{P}$ \\
\hline $\begin{array}{l}\text { Textiles, textile products, leather and } \\
\text { footwear }^{4}\end{array}$ & 74 & 9.3 & $\mathrm{P}$ & $\mathrm{E}$ \\
\hline $\begin{array}{l}\text { Chemicals excluding } \\
\text { pharmaceuticals }^{2}\end{array}$ & 58 & 7.3 & $\mathrm{E} / \mathrm{P}$ & $\mathrm{E}$ \\
\hline $\begin{array}{l}\text { Motor vehicles, trailers and semi- } \\
\text { trailers }^{2}\end{array}$ & 55 & 6.9 & $\mathrm{P}$ & $\mathrm{P}$ \\
\hline $\begin{array}{l}\text { Basic metals and fabricated metal } \\
\text { products }^{3}\end{array}$ & 39 & 4.9 & $\mathrm{E}$ & \\
\hline $\begin{array}{l}\text { Medical, precision and optical } \\
\text { instruments }{ }^{1}\end{array}$ & 39 & 4.9 & $\mathrm{E}$ & \\
\hline $\begin{array}{l}\text { Radio, TV and communications } \\
\text { equipment }{ }^{1}\end{array}$ & 37 & 4.7 & $\mathrm{E}$ & $\mathrm{E} / \mathrm{P}$ \\
\hline Manufacturing, n.e.c.; Recycling ${ }^{4}$ & 30 & 3.8 & $\mathrm{P}$ & $\mathrm{P}$ \\
\hline Other non-metallic mineral products ${ }^{3}$ & 20 & 2.5 & $\mathrm{E} / \mathrm{P}$ & $\mathrm{P}$ \\
\hline $\begin{array}{l}\text { Food products beverages and } \\
\text { tobacco }{ }^{4}\end{array}$ & 19 & 2.4 & & $\mathrm{P}$ \\
\hline Rubber and plastics products ${ }^{3}$ & 19 & 2.4 & $\mathrm{E} / \mathrm{P}$ & $\mathrm{E}$ \\
\hline $\begin{array}{l}\text { Wood, pulp, paper, paper products, } \\
\text { printing and publishing }{ }^{4}\end{array}$ & 15 & 1.9 & & \\
\hline Pharmaceuticals ${ }^{1}$ & 14 & 1.8 & $\mathrm{E}$ & $\mathrm{E} / \mathrm{P}$ \\
\hline $\begin{array}{l}\text { Office, accounting and computing } \\
\text { machinery }{ }^{1}\end{array}$ & 8 & 1.0 & $\mathrm{E}$ & $\mathrm{E} / \mathrm{P}$ \\
\hline $\begin{array}{l}\text { Building and repairing of ships and } \\
\text { boats }^{3}\end{array}$ & 7 & 0.9 & $\mathrm{P}$ & $\mathrm{E}$ \\
\hline $\begin{array}{l}\text { Railroad equipment and transport } \\
\text { equipment, n.e.c. }{ }^{2}\end{array}$ & 7 & 0.9 & $\mathrm{P}$ & $\mathrm{E}$ \\
\hline Aircraft and spacecraft ${ }^{1}$ & 5 & 0.6 & $\mathrm{P}$ & $\mathrm{E}$ \\
\hline Total number of pillar sectors & & & 10 & 9 \\
\hline Total number of emerging sectors & & & 9 & 10 \\
\hline
\end{tabular}

Note: 1 High-technology industries; 2 Medium-high-technology industries; 3 Medium-low-technology industries; 4 Low-technology industries. Source: Own elaboration based on MofCom data \& Five-Year Plans. 
Table B

Variables and data sources.

\begin{tabular}{|c|c|c|}
\hline Variables & Measurement & Data sources \\
\hline \multicolumn{3}{|l|}{ Dependent variables } \\
\hline $\begin{array}{l}\text { Motivation in logistic } \\
\text { regressions }\end{array}$ & $1=$ the specific motivation, $0=$ otherwise & Ministry of Commerce \\
\hline $\begin{array}{l}\text { Motivation in multinomial } \\
\text { logistic regression }\end{array}$ & $\begin{array}{l}1=\text { manufacturing oriented, } 2=\text { sales and service oriented, } 3=\mathrm{R} \& \mathrm{D} \\
\text { oriented }\end{array}$ & Ministry of Commerce \\
\hline \multicolumn{3}{|l|}{ Independent variables } \\
\hline \multicolumn{3}{|c|}{ Industrial competitiveness of host country } \\
\hline Industry R\&D intensity & $\begin{array}{l}\text { Business enterprise R\&D expenditure (BERD) divided by VA of the } \\
\text { sector (EU industry R\&D intensity) }\end{array}$ & Eurostat \\
\hline Sectoral labor productivity & $\begin{array}{l}\text { VA divided by total employment in the specific industry (EU industry } \\
\text { productivity) }\end{array}$ & Eurostat \\
\hline $\begin{array}{l}\text { Importance of Industry in the } \\
\text { economy }\end{array}$ & $\begin{array}{l}\text { Percentage of VA in total manufacturing GDP (EU relevance of the } \\
\text { sector) }\end{array}$ & Eurostat \\
\hline $\begin{array}{l}\text { Evolution of the total VA of the } \\
\text { sector }\end{array}$ & Growth rate of sector VA (EU sectoral growth) & Eurostat \\
\hline \multicolumn{3}{|c|}{ Industrial competitiveness of source country } \\
\hline Industry $R \& D$ intensity & $\begin{array}{l}\text { Sectoral expenditure on } R \& D \text { divided by the revenue from core } \\
\text { business (Chinese industry } R \& D \text { intensity) }\end{array}$ & China Statistical Yearbook \\
\hline Sectoral labor productivity & $\begin{array}{l}\text { The revenue from core business divided by total industry employment } \\
\text { (Chinese industry labor productivity) }\end{array}$ & China Statistical Yearbook \\
\hline $\begin{array}{l}\text { Evolution of sectoral } \\
\text { productivity performance }\end{array}$ & $\begin{array}{l}\text { Growth rate of the revenue from core business divided by total } \\
\text { industry employment (Chinese industry productivity growth) }\end{array}$ & China Statistical Yearbook \\
\hline $\begin{array}{l}\text { Propensity of individual firms } \\
\text { to invest in the sector }\end{array}$ & $\begin{array}{l}\text { Investment in fixed assets divided by total employment (Chinese } \\
\text { industry investment propensity) }\end{array}$ & China Statistical Yearbook \\
\hline \multicolumn{3}{|l|}{ Control variables } \\
\hline Industry category & $1=$ belonging to the category, $0=$ otherwise & Ministry of Commerce \\
\hline Host market size & Log of GDP & Eurostat \\
\hline Host market affluence & Log of GDP per capita & Eurostat \\
\hline Agglomeration effect & $\begin{array}{l}\text { Cumulated number of Chinese investments in all manufacturing } \\
\text { sectors located in the same host country in the year before the new } \\
\text { OFDI occurs }\end{array}$ & Ministry of Commerce \\
\hline Encouraged industries & $\begin{array}{l}1=\text { the industry belongs to the encouraged sectors after 2008, } 0= \\
\text { otherwise. }\end{array}$ & $\begin{array}{l}\text { Guiding Directories of Target Nations and Industries } \\
\text { for OFDI, issued by the State Council of China (2008) }\end{array}$ \\
\hline Prioritized industries & $\begin{array}{l}1=\text { the industry belongs to the pillar or emerging sectors in the } 11 \text { th or } \\
12 \text { th Five Year Plan, } 0=\text { otherwise }\end{array}$ & $\begin{array}{l}\text { Five-Year Plans for National Economic and Social } \\
\text { Development }\end{array}$ \\
\hline Government participation & The percentage of state-owned assets in the industry & National Bureau of statistics of China \\
\hline Industry competition intensity & $\begin{array}{l}\text { The growth in the number of firms with annual revenue of over } 20 \\
\text { million RMB. }\end{array}$ & National Bureau of statistics of China \\
\hline
\end{tabular}

\section{References}

Allison, P. D. (2009). Fixed effects regression models. Sage Publications.

Alon, I., Child, J., Li, S., \& McIntyre, J. R. (2011). Globalization of Chinese firms: Theoretical universalism or particularism. Management and Organization Review, 7(2), 191-200.

Baker, \& McKenzie. (2015). Reaching New Heights: An update on Chinese investment into Europe. Available at: https://www.bakermckenzie.com/-/media/files/insight/ publications/2016/03/reaching-new-heights/ar_emea_reachingnewheights_mar16.pdf? (last access February 4th, 2020).

Balcet, G., Wang, H., \& Richet, X. (2012). Geely: A trajectory of catching up and asset-seeking multinational growth. International Journal of Automotive Technology and Management, 12(4), 360-375.

Barney, J. B. (1991). Firm resources and sustained competitive advantage. Journal of Management, 17, 99-120.

Barrell, R., \& Pain, N. (1999). Domestic institutions, agglomerations and foreign direct investment in Europe. European Economic Review, 43 , $925-934$.

Basile, R., Castellani, D., \& Zanfei, A. (2009). National boundaries and the location of multinational firms in Europe. Papers in Regional Science, 88, 733-748.

Barbieri, E., Di Tommaso, M. R., Tassinari, M., \& Marozzi, M. (2021). Selective industrial policies in China: investigating the choice of pillar industries. International Journal of Emerging Markets, 16(2), 264-282.

Bellak, C., Leibrecht, M., \& Riedl, A. (2008). Labour costs and FDI flows into central and eastern European countries: A survey of the literature and empirical evidence. Structural Change and Economic Dynamics, 19(1), 17-37.

Bijsterbosch, M., \& Kolasa, M. (2010). FDI and productivity convergence in central and Eastern Europe: An industry-level investigation. Review of World Economics, $145,689-712$.

Boter, H., \& Holmquist, C. (1996). Industry characteristics and internationalization processes in small firms. Journal of Business Venturing, 11(6), 471-487.

Buckley, P., Clegg, J., Cross, A., Liu, X., Voss, H., \& Zheng, P. (2007). The determinants of Chinese outward foreign direct investment. Journal of International Business Studies, 38, 499-518.

Buckley, P., Clegg, J., Forsans, N., \& Reilly, K. (2001). Increasing the size of the "country": Regional economic integration and foreign direct Investment in a Globalised World Economy. Management International Review, 41(3), 251-274.

Buckley, P., Clegg, J., Voss, H., Cross, A., Liu, X., \& Zheng, P. (2018). A retrospective and agenda for future research on Chinese outward foreign direct investment. Journal of International Business Studies, 49(1), 4-23.

CEC. (2020). Europe's moment: Repair and prepare for the next generation. Brussels: Commission of the European Communities.

Chen, B., Li, Y., \& Yin, Y. (2016). FDI, industry heterogeneity and employment elasticity in China. Review of Development Economics, 20(1), 189-200. 
Chen, Y. R., Jiang, X., \& Weng, C. H. (2020). Can government industrial policy enhance corporate bidding? The evidence of China. Pacific-Basin Finance Journal, 60, 101288.

Crescenzi, R., Pietrobelli, C., \& Rabellotti, R. (2016). Regional strategic assets and the location strategies of emerging countries' multinationals in Europe. European Planning Studies, 24(4), 645-667.

Cui, L., \& Jiang, F. (2010). Behind ownership decision of Chinese outward FDI: Resources and institutions. Asia Pacific Journal of Management, $27,751-774$.

Cui, L., Jiang, F., \& Stening, B. (2011). The entry-mode decision of Chinese outward FDI: Firm resources, industry conditions, and institutional forces. Thunderbird International Business Review, 53(4), 483-499.

Curran, L., \& Thorpe, M. (2013). Technology and international orientation: Exploring sectoral differences in home region orientation. Multinational Business Review, 21 (1), 25-44.

Cushman, D. O. (1987). The effects of real wages and labor productivity on foreign direct investment. Southern Economic Journal, 54(1), 174-185.

Daniels, J. P., \& Ruhr, M. (2014). Transportation costs and US manufacturing FDI. Review of International Economics, 22(2), 299-309.

Deng, P. (2012). The internationalization of Chinese firms: A critical review and future research. International Journal of Management Reviews, 14 , 408-427.

Deng, P. (2013). Chinese outward direct investment research: Theoretical integration and recommendations. Management and Organization Review, 9(3) (573-539).

Disdier, A. C., \& Mayer, T. (2004). How different is Eastern Europe? Structure and determinants of location choices by French firms in Eastern and Western Europe. Journal of Comparative Economics, 32, 280-296.

Driffield, N., \& Love, J. H. (2007). Linking FDI motivation and host economy productivity effects: Conceptual and empirical analysis. Journal of International Business Studies, 38(3), 460-473.

Duchatel, M. (2020). Living with the EU' s investment screening. China trends \#5. 4th June. Institut Montaigne Accessed at https://www.institutmontaigne.org/en/ blog/china-trends-5-living-eus-investment-screening.

Dunning, J. H. (1993). Multinational enterprises and the global economy. Harlow: Addison-Wesley.

EP.. (2018). State of EU-China relations European Parliament resolution of 12 September (2018) on the state of EU-China relations P8_TA-PROV (2018)0343. Brussels: European Parliament.

Fillat, C., \& Woerz, J. (2011). Good or bad? The influence of FDI on productivity growth. An industry-level analysis. The Journal of International Trade \& Economic Development, 20(3), 293-328.

Ford, S., \& Strange, R. (1999). Where do Japanese manufacturing firms invest within Europe, and why? Transnational Corporations, 8(1), 117-142.

Franco, C., Rentocchini, F., \& Vittucci Marzetti, G. (2010). Why do firms invest abroad? An analysis of the motives underlying foreign direct investments. The IUP Journal of International Business Law, 9(1/2), 42-65.

Gaur, A., Kumar, V., \& Singh, D. (2014). Institutions, resources, and internationalization of emerging economy firms. Journal of World Business, 49(1), 12-20.

Gaur, A., Ma, X., \& Ding, Z. (2018). Home country supportiveness/unfavorableness and outward foreign direct investment in China. Journal of International Business Studies, 49, 324-345.

Gorodnichenko, Y., Svejnar, J., \& Terrell, K. (2014). When does FDI have positive spillovers? Evidence from 17 transition market economies. Journal of Comparative Economics, 42(4), 954-969.

Greenaway, D., \& Kneller, R. (2007). Firm heterogeneity, exporting and foreign direct investment. The Economic Journal, 117, F134-F161.

Haasis, T., \& Liefner, I. (2019). Reviewing the research on the internationalization of Chinese firms: Thematic expansion, new impulses and potential future development. International Journal of Emerging Markets, 14(1), 24-50.

Hausman, J., \& McFadden, D. (1984). Specification tests for the multinomial logit model. Econometrica, 52(5), $1219-1240$.

He, C., Xie, X., \& Zhu, S. (2015). Going global: Understanding China's outward foreign direct investment from motivational and institutional perspectives. PostCommunist Economies, 27(4) (448-47).

He, S., Khan, Z., Lew, Y., \& Fallon, G. (2019). Technological innovation as a source of Chinese multinationals' firm-specific advantages and internationalization. International Journal of Emerging Markets, 14(1), 115-133.

Hejazi, W., \& Pauly, P. (2003). Motivations for FDI and domestic capital formation. Journal of International Business Studies, 34(3), 282-289.

Herzer, D. (2011). The long-run relationship between outward foreign direct investment and Total factor productivity: Evidence for developing countries. Journal of Development Studies, 47(5), 767-785.

Huang, M., Zhang, H., \& Angelino, A. (2017). Chinese pharmaceuticals: Does sub-national marketization matter? Evidence of cross-province acquisitions by Guangdong pharmaceutical firms. International Journal of Healthcare Technology and Management, 16(1/2), 95-107.

Hooijmaaijers, B. (2019). Blackening skies for Chinese investment in the EU? Journal of Chinese Political Science, 24, 451-470.

Huang, Y., \& Zhang, Y. (2017). How does outward foreign direct investment enhance firm productivity? A heterogeneous empirical analysis from Chinese manufacturing. China Economic Review, 44, 1-15.

Jormanainen, I., \& Koveshnikov, P. (2012). International activities of emerging market firms. Management International Review, 52(5), 691-725.

Kamaly, A. (2014). Does FDI crowd in or out domestic investment? New evidence from emerging economies. Modern Economy, 5(4), 391-400.

Knoerich, J. (2017). How does outward foreign direct investment contribute to economic development in less advanced home countries? Oxford Development Studies, 45(4), 443-459.

Knoerich, J. (2019). Re-orienting the paradigm: Path dependence in FDI theory and the emerging multinationals. International Journal of Emerging Markets, 14(1), 51-69.

Knoerich, J., \& Miedtank, T. (2018). Chinese foreign direct investment in the EU. CESifo Forum, 4(19), 3-8.

Kolstad, I., \& Wiig, A. (2012). What determines Chinese outward FDI? Journal of World Business, 47, 26-34.

Leonidou, L., Katsikeas, C., Palihawadana, D., \& Spyropoulou, S. (2007). An analytical review of the factors stimulating smaller firms to export: Implications for policy-makers. International Marketing Review, 24(6), 735-770.

Li, J., Xia, J., Shapiro, D., \& Lin, Z. (2018). Institutional compatibility and the internationalization of Chinese SOEs: The moderating role of home subnational institutions. Journal of World Business, 53(5), 641-652.

Li, L., Liu, X., Yuan, D., \& Yu, M. (2017). Does outward FDI generate higher productivity for emerging economy MNEs? - Micro-level evidence from Chinese manufacturing firms. International Business Review, 26, 839-854.

Lu, J., Liu, X., \& Wang, H. (2011). Motives for outward FDI of Chinese private firms: Firm resources, industry dynamics, and government policies. Management and Organization Review, 7(2), 223-248.

Luo, Y., \& Tan, J. (1997). How much does industry structure impact foreign direct investment in China? International Business Review, 6(4), $337-359$.

Lu, Y., \& Yao, J. (2006). Impact of state ownership and control mechanisms on the performance of group affiliated companies in China. Aisa Pacific Journal of Management, 23, 485-503.

Luo, Y., \& Tung, L. (2007). International expansion of emerging market enterprises: A springboard perspective. Journal of International Business Studies, 38(4), $481-498$.

Luo, Y., Xue, Q., \& Han, B. (2010). How emerging market governments promote outward FDI: Experience from China. Journal of World Business, 45, 68-79.

Luo, Y., \& Zhang, H. (2016). Emerging market MNEs: Qualitative review and theoretical directions. Journal of International Management, 22(4), 333-350.

Lv, P., \& Spigarelli, F. (2015). The integration of Chinese and European renewable energy markets: The role of Chinese foreign direct investments. Energy Policy, 81, 14-26.

Makino, S., Lau, C. M., \& Yeh, R. S. (2002). Asset- exploitation versus asset seeking: Implication for location choice of foreign direct investment from newly industrialized economies. Journal of International Business Studies, 33(3), 403-421.

Mathews. (2002). Dragon multinational: Towards a new model of global growth. NewYork: Oxford University Press.

Morck, R., Yeung, B., \& Zhao, M. (2008). Perspectives on China's outward foreign direct investment. Journal of International Business Studies, 39, 337-350.

Nicolas, F. (2014). China's direct investment in the European Union: Challenges and policy responses. China Economic Journal, 7(1), 103-125. 
OECD. (2013). ISIC REV. 3 Technology Intensity Definition. Organization for Economic Co-operation and: Development. https://www.oecd.org/sti/ind/48350231.pdf. (Accessed 12 June 2016).

Paul, J., \& Benito, G. (2018). A review of research on outward foreign direct investment from emerging countries, including China: What do we know, how do we know and where should we be heading? Asia Pacific Business Review, 24(1), 90-115.

Peng, M., Wang, D., \& Jiang, Y. (2008). An institution-based view of international business strategy: A focus on emerging economies. Journal of International Business Studies, 39(5), 920-936.

Plechero, M., \& Chaminade, C. (2013). The influence of micro-characteristics and the region in different modes of globalization of innovation: A comparative study of Pune region and Beijing region. Industry and Innovation, 20(7), 661-682.

Porter, M. E. (1990). The competitive advantage of nations. London: Macmillan.

Ramamurti, R., \& Hillemann, J. (2018). What is "Chinese" about Chinese multinationals? Journal of International Business Studies, 49(1), 34-48.

Ramasamy, B., Yeung, M., \& Laforet, S. (2012). China' s outward foreign direct investment: Location choice and firm ownership. Journal of World Business, 47(1), $17-25$.

Rasciute, S., \& Pentecost, E. J. (2010). A nested logit approach to modelling the location of foreign direct investment in the central and eastern European countries. Economic Modelling, 27, 32-39.

Rasciute, S., Pentecost, E. J., \& Ferret, B. (2014). Firm heterogeneity in modelling foreign direct investment location decisions. Applied Economics, 46(12), 1350-1360.

Rath, B. N., \& Bal, D. P. (2014). Do FDI and public investment crowd in or crowd out private domestic Investment in India. The Journal of Developing Areas, 48(3), 269-284.

Schmitz, H. (2000). Does local co-operation matter? Evidence from industrial clusters in South Asia and Latin America. Oxford Development Studies, 28(3), 323-336.

Shan, W., \& Song, J. (1997). Foreign Direct Investment and the Sourcing of Technological Advantage: Evidence from the Biotechnology Industry. Journal of International Business Studies, 28, 267-284.

Spigarelli, F., Alon, I., \& Mucelli, A. (2015). Chinese M \& a in Europe: Emerging market multinational in the heavy construction industry. Competitiveness Review, 25 (4), 346-370.

State Council of China. (2008). Catalogue for the Guidance of Industries for Foreign Investment (Revised in 2007). Available at: http://english.www.gov.cn/archive/ state_council_gazette/2015/06/08/content_281475123275121.htm (last access July 5th, 2021).

Trevino, L. J., \& Grosse, R. (2002). An analysis of firm-specific resources and foreign direct investment in the United States. International Business Review, 11, 431-452.

UNCTAD. (2018). World Investment Report 2018. Geneva: United Nations Conference on Trade and Development.

UNCTAD. (2020). World Investment Report 2020. Geneva: United Nations Conference on Trade and Development.

Wang, C., Hong, J., Kafouros, M., \& Boateng, A. (2012). What drives outward FDI of Chinese firms? Testing the explanatory power of three theoretical frameworks. International Business Review, 21, 425-438.

Xie, Z., \& Li, J. (2018). Exporting and innovating among emerging market firms: The moderating role of institutional development. Journal of International Business Studies, 49(2), 222-245.

Yan, B., Zhang, Y., Yanzhi, S., \& Jian, H. (2018). Productivity, financial constraints and outward foreign direct investment: Firm-level evidence. China Economic Review, 47, 47-64.

Yang, X., Jiang, Y., Kang, R., \& Ke, Y. (2009). A comparative analysis of the internationalization of Chinese and Japanese firms. Asia Pacific Journal of Management, 26 (1), 141-162.

Yang, X., Lim, Y., Sakurai, Y., \& Seo, S. (2009). Internationalization of Chinese and Korean firms. Thunderbird International Business Review, 51(1), 37-51.

You, K., \& Solomon, O. H. (2015). China's outward foreign direct investment and domestic investment: An industrial level analysis. China Economic Review, 34, 249-260.

Zhang, Y., \& Roelfsema, H. (2013). Unravelling the complex motivations behind China's outward FDI. Journal of Asia Pacific Economy, 19(1), 89-100.

Zhang, Z. (2002). Productivity and economic growth: An empirical assessment of the contribution of FDI to the Chinese economy. Journal of Economic Development, 27 (2), 81-94. 